Volume 58

Issue 4 Solving Global Problems: Perspectives

from International Law and Policy

January 2014

\title{
The Geography of Solving Global Environmental Problems: Reflections on Polycentric Efforts to Address Climate Change
}

HARI M. OSOFSKY

Professor at the University of Minnesota Law School

Follow this and additional works at: https://digitalcommons.nyls.edu/nyls_law_review

Part of the Environmental Law Commons

\section{Recommended Citation}

HARI M. OSOFSKY, The Geography of Solving Global Environmental Problems: Reflections on Polycentric Efforts to Address Climate Change, 58 N.Y.L. SCH. L. REV. (2013-2014).

This Article is brought to you for free and open access by DigitalCommons@NYLS. It has been accepted for inclusion in NYLS Law Review by an authorized editor of DigitalCommons@NYLS. 


\title{
The Geography of Solving Global Environmental Problems: Reflections on Polycentric Efforts to Address Climate Change
}

\author{
58 N.Y.L. Sch. L. Rev. 777 (2013-2014)
}

\begin{abstract}
ABOUT THE AUTHOR: Hari M. Osofsky is a Professor at the University of Minnesota Law School; 2013-14 Fesler-Lampert Chair in Urban and Regional Affairs; Director of the Joint Degree Program in Law, Science \& Technology; Faculty Member of the Conservation Biology Graduate Program; Adjunct Professor of the Department of Geography, Environment and Society; and Fellow of the Institute on the Environment. This essay contains edited portions of Hari M. Osofsky, Suburban Climate Change Efforts: Possibilities for Small and Nimble Cities Participating in State, Regional, National, and International Networks, 22 Connelu J.L. \& Puв. Pol'y 395 (2012) and Hari M. Osofsky, Climate Change and Crises of International Law: Possibilities for Geographic Reenvisioning, 44 CASE W. Res. J. INT'L L. 423 (2011). The author very much appreciates the helpful suggestions from both academics and state and local officials on this project on suburbs and climate change-including Sarah Bronin, Tai-Heng Cheng, Jessica Clarke, Kirsten Engel, Daniel Farber, Michael Gerrard, Alexandra Klass, Peter Lindstrom, Beth Mercer-Taylor, Philipp Muessig, Amir Nadav, Ashira Ostrow, Pierre-Henri Prelot, Ben Richardson, and Ruti Teitel-which have helped her shape this project and ensure that it reflects the on-the-ground experiences in the Twin Cities metropolitan region. The author is also grateful to Myron Orfield for allowing her to reproduce his map of the Twin Cities divided by type of suburb. This essay's ideas have been significantly improved by the insights of participants in workshops at the Emory University School of Law, Georgetown University Law Center, New York Law School, University of British Columbia Law School, University of Minnesota Law School, and Washington University School of Law. Kenzie Johnson provided invaluable research assistance on the case studies of individual cities and their involvement in multilevel networks, and helped to design the charts in Table 2 and the Appendix; David Warden also provided helpful research assistance on the efforts of Minneapolis and Saint Paul and on the limitations of the current data on measurable emissions reductions by the suburbs studied; and Joseph Dammel assisted greatly with crucial updating and finalizing of the piece, as well as with locating missing sources. The Law Library at the University of Minnesota Law School, and particularly Suzanne Thorpe, was extremely helpful, especially in locating interdisciplinary sources on suburbs and climate change. The author also thanks Meghan Schwartz for her assistance with formatting, and Asher Hawkins, William Lemon, and G. William Bartholomew of the New York Law School Law Review for their thoughtful editorial work. The author was greatly assisted by the financial support of the 2011 Lampert Fesler Research Fellowship, the 2011-14 Institute on the Environment Fellowship, and an award from the University of Minnesota's Institute for Advanced Studies. The author is, as always, grateful for the love, support, and patience of Josh, Oz, and Scarlet Gitelson.
\end{abstract}




\section{THE GEOGRAPHY OF SOLVING GLOBAL ENVIRONMENTAL PROBLEMS}

\section{INTRODUCTION}

In approaching the symposium topic of "solving global environmental problems,"1 I faced three dilemmas regarding the problem-climate change-that has occupied much of my time over the past several years. First, I do not regard it as "global." While certainly climate change has global dimensions, which makes attempts to solve it through international law critical, the problem is deeply multiscalar both physically and legally. As I have explored in my prior work, emissions by specific people and entities in particular places interact with a complex ocean-atmospherelandmass system in ways that result in specific impacts in particular places that scientists can predict with varying levels of certainty. Every level of government in each country around the world, and individuals and community groups at sublocal levels, make choices that impact both mitigation and adaptation in ways that no global regime could fully capture. ${ }^{2}$

Second, climate change is not just environmental. Climate change interacts with many different substantive areas of law at multiple levels of government. Because a large percentage of emissions result from the production and use of energy in electricity and transportation, energy law, corporate law, tax law, and land use planning law, just to name a few of the most critical, all play important roles. Moreover, many key energy companies are multinational entities, but primarily regulated at national and subnational levels, additionally complexifying the legal picture. This state-corporate regulatory dynamic further muddies how to characterize the scale of this problem and legal efforts to address it; the energy industry is transnational, but little "global" law directly regulates it. ${ }^{3}$

Third, I am not sure climate change can be solved. Although climate change is a critical problem that humanity needs to solve, it has been accurately characterized by Professor Richard Lazarus as "super wicked." While in theory we could address this problem through a rigorous treaty regime paired with aggressive national enforcement efforts that involve mandates to critical subnational entities, such a solution is not politically realistic. I fear that due to (1) the timelag between emissions and their impacts and (2) deep inequalities between major emitters and those facing the most

1. This essay was presented at the New York Law School Law Review symposium Solving Global Problems: Perspectives from International Law and Policy, held at New York Law School on April 12, 2013. A video recording of the presentation is available at http://youtu.be/AmCj9FX0abc.

2. See Hari M. Osofsky, Is Climate Change "International"? Litigation's Diagonal Regulatory Role, 49 VA. J. INT'L L. 585 (2009).

3. Hari M. Osofsky, The Geography of Climate Change Litigation: Implications for Transnational Regulatory Governance, 83 Wash. U. L.Q. 1789, 1814-15 (2005).

4. Richard J. Lazarus, Super Wicked Problems and Climate Change: Restraining the Present to Liberate the Future, 94 Cornell L. Rev. 1153, 1159 (2009) (citing Horst W.J. Rittel \& Melvin M. Webber, Dilemmas in a General Theory of Planning, 4 Pol'y Sci. 155, 160-69 (1973); Jefrreey Conklin, Dialogue Mapping: Building Shared Understanding of Wicked Problems 3-40 (2006)) ("Scholars long ago characterized a public-policy problem with the kinds of features presented by climate change as a 'wicked problem' that defies resolution because of the enormous interdependencies, uncertainties, circularities, and conflicting stakeholders implicated by any effort to develop a solution.”). 
immediate severe impacts, by the time humanity is willing to face up to the hard choices posed by this problem, the choices will be very stark indeed. Professor Lesley McAllister and I close our casebook, Climate Change Law and Policy, with two troubling scenarios for the future, major climate change and geoengineering, out of a sense that we are not currently on a path toward adequate mitigation. ${ }^{5}$

Given these dilemmas, I initially considered simply focusing on other problems for this symposium. After all, there is a whole range of problems that international environmental law addresses much more comfortably and effectively than climate change. The Oxford Handbook of International Environmental Law, for instance, maps the evolving contours of international environmental law as it tackles the atmosphere and outer space, ocean and freshwater resources, biological resources, and hazardous substances and activities. ${ }^{6}$ Even regarding the problem of climate change, if one looks outside the treaty regime directly focused on that problem, a clear example of an effective international regime making measureable progress exists-the Montreal Protocol. That treaty's successful efforts to address ozone depletion over time, made much easier by clear causes with commercially viable substitutes, have also helped to eliminate potent greenhouse gases. ${ }^{7}$

However, if we are going to have a meaningful conversation about solving global problems, we cannot avoid really hard problems. Climate change is not only a problem that may be impossible to solve, but also one that raises difficult questions about how we should conceptualize international law. This essay attempts to take on that challenge. It grapples with the symposium's topic, "solving global problems," by focusing on the complex geography of climate change and the law that attempts to address it.

This essay considers how we might fit local efforts to address climate change, especially those by very small, suburban cities, within our problem-solving models. While acknowledging the need for more action on climate change at international, national, and state levels, and regional ones in between, this essay explores how different types of cities, as they participate in multilevel networks, can provide models for action and complement efforts to address climate change through the treaty regime. ${ }^{8}$

5. Hari M. Osofsky \& Lesley K. McAllister, Climate Change Law and Policy 378-428 (2012). The 2014 Intergovernmental Panel on Climate Change report from Working Group III on mitigation notes in its policy summary that "[e]stimated global GHG emissions levels in 2020 based on the Cancún Pledges are not consistent with cost-effective long-term mitigation trajectories that are at least as likely as not to limit temperature change to $2^{\circ} \mathrm{C}$ relative to pre-industrial levels . . . but they do not preclude the option to meet that goal .... Meeting this goal would require further substantial reductions beyond 2020." Intergovernmental Panel on Chimate Change, Climate Change 2014: Mitigation of Climate Change-Summary for Policymakers 15 (2014), available at http://report.mitigation 2014. org/spm/ipcc_wg3_ar5_summary-for-policymakers_approved.pdf.

6. See generally The Oxford Handbook of International Environmental Law (Daniel Bodansky, Jutta Brunnée \& Ellen Hey eds., 2007), reviewed by Hari M. Osofsky, Book Review, 106 Am. J. InT'L L. 715 (2012).

7. See infra notes $23-24$ and accompanying text.

8. In this essay, I use the term "city" to refer to any type of city, whether central city, suburb, exurb, or rural city. I use the term "suburb" to refer to cities that are part of a metropolitan area but are not the central 


\section{THE GEOGRAPHY OF SOLVING GLOBAL ENVIRONMENTAL PROBLEMS}

Using a diverse group of suburbs in the Twin Cities metropolitan region making innovative climate change and sustainability efforts as a case example, it analyzes pathways for small governments - which may be more nimble due to their geographic size and smaller number of people in charge-to: (1) learn from other localities and find cost-effective approaches to reducing emissions, and (2) serve as a constructive influence on national and international efforts to address climate change.

The Twin Cities metropolitan region provides an interesting case study for considering suburban action on climate change as part of global problem solving because its central cities, Minneapolis and Saint Paul, have leading mitigation efforts and, at the state level, Minnesota has established a structured program to support urban sustainability efforts. ${ }^{9}$ Moreover, some of its suburbs-including ones that lean Republican-have been particularly innovative in their efforts to achieve rapid progress in reducing greenhouse gas emissions, at times even receiving national recognition. Together with the metropolitan region's combination of fragmentation and significant regional governance, these climate change and sustainability efforts provide a rich context in which to analyze pathways for suburban emissions reduction as part of addressing the "global" problem of climate change. This essay acknowledges, however, that these very characteristics that make the example interesting may also constrain its broader applicability and replicability, an issue that I am addressing through conducting a broader study of six major metroregions that will be the subject of future scholarship. ${ }^{10}$

This essay begins in Part II by describing the failure of international law to address climate change and the implications of that failure for global problem solving. Part III then draws from four streams of interdisciplinary theory to conceptualize local, and particularly suburban, climate change initiatives as part of global problem solving. Part IV provides a case study of suburban climate change action in the Twin Cities metropolitan region to illustrate the complex nuances of a more polycentric approach to climate change. The essay concludes with reflections on how this example fits into the symposium's broader conversation.

cities. I use the term "multilevel" to refer to governmental or nongovernmental entities that are constituted at or interact with more than one level of government (e.g., local, state, national, international, regional).

9. See Minn. GreenStep Cities, http://greenstep.pca.state.mn.us/index.cfm (last visited Mar. 29, 2014).

10. For example, this essay does not attempt to tackle how these patterns compare to those of other regions in the United States that have less well-developed regional governments, cover larger physical areas, or contain central cities engaged in aggressive annexation. A full national study is beyond the scope of this essay, but this initial look at one particularly innovative metropolitan region and the efforts of some of its suburbs helps to frame questions and potential strategies for a broader study that I am conducting this academic year with support from the 2013-14 Fesler-Lampert Chair in Urban and Regional Affairs. For the first article to result from that broader study, which considers participation in multilevel climate change networks by city type in six major metroregions, see Hari M. Osofsky, Rethinking the Geography of Local Climate Action: Multi-Level Network Participation in Metropolitan Regions, 2015 UTAH L. Rev. (forthcoming 2015). 


\section{CHALLENGES FACING GLOBAL EFFORTS TO SOLVE CLIMATE CHANGE}

As a formal matter, international legal efforts to address climate change fit within a traditional model of solving problems regarded as global in scope through treaties. The dominant multilateral climate change regime consists of the U.N. Framework Convention on Climate Change (UNFCCC) ${ }^{11}$ and agreements negotiated under that convention. The UNFCCC provides general commitments and a structure for achieving more specific targets and timetables. ${ }^{12}$ Parties to the UNFCCC meet regularly in conferences under its auspices, most recently in Warsaw, Poland in 2013, to attempt to negotiate additional agreements. The 2011 Conference of the Parties (COP) in Durban, South Africa resulted in an agreement to reach a universal agreement by 2015 and established the Durban Platform process to begin negotiating toward this 2015 goal. ${ }^{13}$ These efforts are complemented by the December 2012 decision of thirty-seven of the parties to the Kyoto Protoco $1{ }^{14}$ - the only agreement negotiated under the UNFCCC that provides binding targets and timetables- to extend the Protocol to a second commitment period running from 2013 to $2020 .{ }^{15}$

However, both this international-level approach and a traditional narrative of it face two difficult challenges. First, and least problematically for an account in which we "solve global problems" through international treaties, the existing regime and negotiations are struggling to achieve their goals. ${ }^{16}$ The Kyoto Protocol's first period commitments were not enough to close the emissions gap, and some parties failed to meet even those limited commitments. Moreover, participation by important developed country emitters in the Kyoto regime is declining. Despite its active role in initial negotiations, the United States, the largest total developed country emitter, ${ }^{17}$

11. U.N. Framework Convention on Climate Change, opened for signature June 4, 1992, S. Treaty Doc. No. 102-38, 1771 U.N.T.S. 107 (entered into force Mar. 21, 1994) [hereinafter UNFCCC].

12. See generally id.

13. See UNFCCC Decision 1/CP.17, Establishment of an Ad Hoc Working Group on the Durban Platform for Enhanced Action, 17th Sess., Nov. 28-Dec. 11, 2011, CP/2011/9/Add.1, at 2-3 (Dec. 11, 2011) [hereinafter Durban Platform AWG Decision], available at http://unfccc.int/resource/docs/2011/cop17/ eng/09a01.pdf.

14. Kyoto Protocol to the U.N. Framework Convention on Climate Change, opened for signature Mar. 16, 1998, 2303 U.N.T.S. 148 (entered into force Feb. 16, 2005).

15. See Conference of the Parties Serving as the Meeting of the Parties to the Kyoto Protocol, Doha, Qatar, Nov. 26-Dec. 7, 2012, Rep. of the Ad Hoc Working Group on Further Commitments for Annex I Parties Under the Kyoto Protocol, U.N. Doc. FCCC/KP/CMP/2012/L.9, Annex I (Dec. 8, 2012) [hereinafter Doha AWG Report], available at http://unfccc.int/resource/docs/2012/cmp8/eng/109.pdf.

16. I have explored these failures in my prior scholarship. See, e.g., Osofsky, supra note 2.

17. The United States is the second-largest total greenhouse gas emitter in the world, after China. LARRY Parker \& John Blodgett, Cong. Research Serv., Rl32721, Greenhouse Gas Emissions: Perspective on the Top 20 Emitters and Developed Versus Developing Nations (2010); Mark McCormick \& Paul Scruton, An Atlas of Pollution: The World in Carbon Dioxide Emissions, The Guardian (Jan. 31, 2011, 2:30 PM), http://image.guardian.co.uk/sys-files/Guardian/documents/2011/02/10/ CarbonWeb.pdf?guni=Graphic:in\%20body\%20link. 


\section{THE GEOGRAPHY OF SOLVING GLOBAL ENVIRONMENTAL PROBLEMS}

never joined. ${ }^{18}$ Key emitters that participated in the first commitment period-most notably, Canada, Japan, and Russia—are not making second period commitments. ${ }^{19}$ Even if nations successfully negotiate a rigorous universal agreement under the Durban Platform process, which seems unlikely, such an agreement will not come into effect until we are even further down the path of inadequate mitigation. ${ }^{20}$

These difficulties do not necessarily suggest the need for innovative theorizing about global problem solving. A Westphalian ${ }^{21}$ narrative of such problem solving, which focuses on international law arising from the consent of sovereign and equal nationstates, would likely acknowledge the regime as creating limited international legal obligations and assess it as not entirely successful in achieving its goals. ${ }^{22}$ However, the substantive problem of addressing climate change effectively through international law would remain. A core question that this essay asks is whether current international legal efforts should focus primarily on achieving better agreements in negotiations among nation-state parties, or whether more inclusive conceptions of global problem solving that shift that focus somewhat might actually serve as a tool in solving this problem.

Second, and more fundamentally, there is a great deal of activity with legal significance on climate change outside of the UNFCCC structure. Some of this activity includes a wide range of additional formal international legal agreements among nation-states, which, for completeness, should be included in even a traditional account of international law creation. ${ }^{23}$ For example, as noted in the introduction, the Montreal Protocol's ${ }^{24}$ efforts to address ozone impact greenhouse gas emissions significantly. ${ }^{25}$ In addition, and less acknowledged in most of the commentary on the UNFCCC, nations have crafted many bilateral and multilateral agreements (with

18. See generally Legal Aspects of Implementing the Kyoto Protocol Mechanisms: Making Күото Work (David Freestone \& Charlotte Streck eds., 2005); see also Russia and the Күото Protocol: Opportunities and Challenges (Anna Korppoo et al. eds., 2006); Alastair R. Lucas, Mythology, Fantasy and Federalism: Canadian Climate Change Policy and Law, 20 PAc. McGeorge Global Bus. \& Dev. L.J. 41, 52-56 (2007).

19. Doha AWG Report, supra note 15 .

20. See Durban Platform AWG Decision, supra note 13.

21. By "Westphalian," I mean guided by the core notions of nation-states as primary subjects and objects of international law and of international law being created through the consent of sovereign and equal nation-states. For expositions of Westphalian understandings of international law, see Ian BrownLie, Principles of Public International Law 287-88 (6th ed. 2003), and Michael J. Kelly, Pulling at the Threads of Westphalia: "Involuntary Sovereignty Waiver"-Revolutionary International Legal Theory or Return to Rule by the Great Powers?, 10 UCLA J. Int'L L. \& Foreign Aff. 361, 383 (2005).

22. See supra notes $16-20$ and accompanying text.

23. I have discussed some of this activity in Hari M. Osofsky, Diagonal Federalism and Climate Change: Implications for the Obama Administration, 62 ALA. L. Rev. 237 (2011).

24. Montreal Protocol on Substances that Deplete the Ozone Layer art. 5, opened for signature Sept. 16, 1987, 1522 U.N.T.S. 3 (entered into force Jan. 1, 1989).

25. For an analysis of the relationship between the Montreal Protocol and climate change and a proposal for the future, see Mark W. Roberts \& Peter M. Grabiel, A Window of Opportunity: Combating Climate Change by Amending the Montreal Protocol to Regulate the Production and Consumption of HFCs and ODS Banks, 22 Geo. Int'L Envtl. L. Rev. 99 (2009). 
fewer parties) on relevant issues such as renewable energy. ${ }^{26}$ These agreements arguably should also be included in almost any account of problem solving relevant to climate change.

The conceptual conundrum comes not from these additional formal agreements among nation-states-though they contribute to the simultaneous overlap and fragmentation of international law-but rather from the many other less formally binding agreements among nation-states and among a wider range of governmental and nongovernmental entities. The agreements reached among cities, states, and provinces during negotiations parallel to the last several COPs-discussed in more depth in Part IV-exemplify this difficulty particularly well because they include subnational governments from nation-states that were having difficulty reaching agreement and the pledges within them represent massive quantities of emissions reductions. ${ }^{27}$

These agreements have no formal international legal significance under traditional notions of international law. They are formed among subnational actors that are not the subjects and objects of international law, and therefore could rescind their commitments at any time. The commitments themselves involve subnational, not international, legal action. Moreover, under the Statute of the International Court of Justice, they would not serve as sources of international law. They are not treaties, and are unlikely to be treated as evidence of nation-states' customary international law obligations or of the general legal principles that they recognize. ${ }^{28}$

As with the first problem of insufficient formal international law, this second issue could be understood through a traditional, Westphalian approach to global problem solving. These subnational agreements do not need formal international legal significance to supplement the international legal efforts by nation-states under the UNFCCC. The subnational efforts can be treated as part of the nation-state meeting its commitments. However, such an understanding captures the transnational aspects of the subnational activities in a rather limited fashion; the transnational agreements are legally insignificant, and the coalitions only matter to international law-making to the extent that they influence nation-states' behavior in the UNFCCC meetings or help them to meet their commitments. ${ }^{29}$ The Part that follows draws from four streams of theory to explore an alternative, more polycentric vision for how local climate change efforts might fit into global problem solving.

26. See, e.g., Int'1 Council on Clean Transp., Athens Resolution (2010); Press Release, The White House, U.S.-China Energy Announcements (Nov. 17, 2009), available at http://www.whitehouse.gov/thepress-office/us-china-clean-energy-announcements; Press Release, The White House, U.S.-Mexico Announce Bilateral Framework on Clean Energy and Climate Change (Apr. 16, 2009), available at http://www.whitehouse.gov/the_press_office/US-Mexico-Announce-Bilateral-Framework-on-CleanEnergy-and-Climate-Change.

27. I have previously analyzed these agreements and the dilemmas that they pose for international lawmaking in Hari M. Osofsky, Multiscalar Governance and Climate Change: Reflections on the Role of States and Cities at Copenhagen, 25 Md. J. InT'L L. 64 (2010).

28. See Statute of the International Court of Justice art. 38, June 26, 1945, 59 Stat. 1055, 33 U.N.T.S. 993 (listing sources to be used by the International Court of Justice).

29. See supra note 21 and accompanying text. 
THE GEOGRAPHY OF SOLVING GLOBAL ENVIRONMENTAL PROBLEMS

\section{CONCEPTUALIZING LOCAL EFFORTS TO ADDRESS CLIMATE CHANGE AS PART OF POLYCENTRIC PROBLEM SOLVING}

As international negotiations and U.S. federal efforts continue to fail to produce an adequate response to climate change, ${ }^{30}$ a growing number of cities-including many small suburban cities - are playing critical roles in multilevel efforts to address climate change. Former U.S. Environmental Protection Agency (EPA) Administrator Lisa Jackson noted in a January 2012 presentation that "those local efforts are where the action is right now." ${ }^{31}$ Especially as global and national trends toward urbanization continue, ${ }^{32}$ cities are becoming increasingly important sites for mitigation and adaptation. Their local land use planning helps to determine per capita emissions and preparedness for changes in the physical environment. ${ }^{33}$ Moreover, leader cities are often ahead of their national governments. These cities form ever-stronger intersecting, multilevel networks in which they make voluntary pledges to reduce emissions and through which they pressure national governments. ${ }^{34}$

However, the piecemeal nature of these urban efforts to address climate change constrains their overall impact. In the United States, for example, 1,054 mayors, representing a total population of more than $88,920,962$ citizens, have joined the U.S. Conference of Mayors Climate Protection Agreement ("Mayors Agreement") in which they pledge to meet what the U.S. commitments under the Kyoto Protocol would have been: reducing emissions to 7\% below 1990 levels by 2012. ${ }^{35}$ While this number is impressive against the current political backdrop in which U.S. political leaders cannot agree on a coherent pathway forward, these mayors represent only

30. This essay assumes that the consensus climate change science synthesized by the Intergovernmental Panel on Climate Change is correct. See Intergovernmental Panel on Climate Change, Climate ChANGe 2007, at 37 (2007), available at http://www.ipcc.ch/pdf/assessment-report/ar4/syr/ar4_syr.pdf. An in-depth discussion of challenges to climate change science is beyond the scope of this essay. I have explored these challenges elsewhere in more detail. See Osofsky \& McAllister, supra note 5, at 4-25. For an assessment of the emissions gap published at the time of the 2011 Durban conference, see U.N. Env't Programme, Bridging the Emissions Gap (2011), available at http://www.unep.org/pdf/ UNEP_bridging_gap.pdf.

31. Lisa P. Jackson, Adm'r, U.S. Envtl. Prot. Agency, Speech at the University of Minnesota (Jan. 17, 2012), available at http://mediamill.cla.umn.edu/mediamill/display/144205 (notes on speech on file with author).

32. For analyses of the complexities of urbanization and environmental management, see Robert H. Freilich \& S. Mark White, Transportation Congestion and Growth Management: Comprehensive Approaches to Resolving America's Major Quality of Life Crisis, 24 Loy. L.A. L. Rev. 915 (1991); G.S. Kleppel, Urbanization and Environmental Quality: Implications of Alternative Development Scenarios, 8 ALB. L. Envtl. Outцоок J. 37 (2002); Edward H. Ziegler, China's Cities, Globalization, and Sustainable Development: Comparative Thoughts on Urban Planning, Energy, and Environmental Policy, 5 WAsH. U. Global Stud. L. Rev. 295, 302 (2006).

33. See infra Part III.A.

34. See infra Part III.B.

35. List of Participating Mayors, Mayors Climate Protection Center, http://www.usmayors.org/ climateprotection/list.asp (last visited Mar. 29, 2014); About the Mayors Climate Protection Center, Mayors Climate Protection Center, http://www.usmayors.org/climateprotection/about.htm (last visited Mar. 29, 2014). 
about $5 \%$ of U.S. cities and $28 \%$ of the total U.S. population. ${ }^{36}$ The vast majority of cities and people are not participating in the Mayors Agreement. Even if a number of cities that have not joined the Agreement for political reasons are still taking significant mitigation reduction steps, a problematic gap in the Mayors Agreement's coverage remains.

Suburbs play a critical role in the United States' capacity to address this gap. They contain the majority of population and emissions in metropolitan areas and most of them have not joined the Mayors Agreement. ${ }^{37}$ A rich scholarly literature across many disciplines documents that, in comparison to their central cities, suburbs as a whole sprawl more, have a higher per capita carbon footprint, and are less likely to take action on climate change, a trio of concerns that are intertwined with inequality and segregation. ${ }^{38}$ These problems have led many to call for larger-scale governmental mandates-especially state and metropolitan regional ones at times in conjunction with national-level action - to force suburbs to reduce their emissions and to address the difficulties of metropolitan regions more broadly. ${ }^{39}$

These analyses, while validly characterizing suburbs in the aggregate and often proposing laudatory policies, have two significant limitations. First, they do not engage fully the diversity of the cities within suburbs; first-ring stressed cities have different needs and mitigation pathways than do the first- and second-ring developed job centers or the faster-growing developing job centers and bedroom communities in the second and third ring and beyond. ${ }^{40}$ While mandates could force action by all cities, understanding how a city's positionality within a metropolitan region affects appropriate action could help guide models targeted to different types of suburbs. Second, the U.S. Congress and many state legislatures are not likely to pass legislation mandating local emissions reductions or even more comprehensive land use planning

36. The U.S. Census Bureau estimated that as of March 29, 2014, the United States had a total population of 317,775,049 people. U.S. and World Population Clock, U.S. Census Bureau, http://www.census.gov/ popclock (last visited Mar. 29, 2014). For a 2012 analysis by the U.S. Census Bureau of the percentage of the population living in municipal and urban areas, see U.S. Census Bureau, Local Governments By TYPe And State: 2012 (2012), available at http://www2.census.gov/govs/cog/2012/formatted prelim_counts_23ju12012_2.pdf (showing that municipalities account for 19,522 of the 35,886 subcounty units). See also 2010 Census Urban Areas FAQs, U.S. Census Bureau, http://www.census.gov/ geo/reference/ua/uafaq.html (last visited Mar. 29, 2014) (noting that urban areas, which are defined as areas containing more than 2,500 residents, represent more than 249 million people in the United States, or $80.7 \%$ of the U.S. population). According to the National League of Cities, "the U.S. Census Bureau (2007) counted 39,044 general purpose local governments, which includes 19,492 municipal governments, 16,519 township governments and 3,033 county governments." Number of Municipal Governments $\&$ Population Distribution, NAT'L League of Cities, http://www.nlc.org/build-skillsand-networks/resources/cities-101/city-structures/number-of-municipal-governments-and-populationdistribution (last visited Apr. 16, 2014).

37. See List of Participating Mayors, supra note 35.

38. See id.

39. $I d$.

40. When referencing "rings," I am referring to how close the cities are to the center city in the metropolitan region. First-ring suburbs are the ones that surround the center cities, second-ring suburbs are the next layer out, etc. 


\section{THE GEOGRAPHY OF SOLVING GLOBAL ENVIRONMENTAL PROBLEMS}

in the near term. Although making a case for this legislation is important to envisioning functional multilevel approaches, we also need strategies for making progress on suburban emissions in the absence of top-down, forcing action.

Four streams of well-developed scholarship provide a basis for understanding suburban action on climate change, both within each individual city and in interaction with multilevel networks. First, an ever-growing scholarly and policy literature explores the role that cities can and should play in responding to the problem of climate change. Some of this literature addresses suburbs, but mostly in the aggregate, as a part of the metropolitan region that has a greater carbon footprint, sprawls, and engages less with multilevel networks. ${ }^{41}$ Second, a rich and rapidly developing literature in law, geography, and urban studies dissects the way in which suburbs are changing and the differences among individual suburbs. While this literature has addressed sustainability to some extent, it has not considered how different suburbs might respond to climate change. ${ }^{42}$ Third, scholars in numerous disciplines have explored the way in which cities form and interact with networks. Some of this scholarship has focused on climate change networks among localities in particular and their interaction with U.S. federalism, including potential domestic mechanisms, but it has not separated out suburbs. ${ }^{43}$ Fourth, a broader stream of scholarship, not focused on cities in particular, has called for pluralist or polycentric approaches to climate change governance. This literature has not yet provided in-depth analysis of mechanisms for integrating multilevel efforts by cities or smaller city suburbs into a governance scheme. ${ }^{44}$

This Part intertwines these streams of scholarship to frame this essay's conceptual approach. Part III.A provides an overview of the current scholarly discourse on cities, suburbs, and climate change, and explains how the literature on the complex demography of suburbs could complement it to frame Part IV's analysis of Twin Cities suburbs. Part III.B brings together scholarship on networks and multilevel governance with the literature on pluralist and polycentric climate change governance to ground Part III's examination of the current and potential role of climate change networks in the suburban context.

\section{A. Local Climate Change Action and Suburban Demographics}

As localities increasingly take actions within their power to mitigate (and also adapt), academics and policymaking institutes have considered the appropriate role of local action in addressing climate change. ${ }^{45}$ This literature provides an important

41. For a discussion of this literature, see infra Part III.A.

42. For a discussion of this literature, see infra Part III.A.

43. For a discussion of this literature, see infra Part III.B.

44. For a discussion of this literature, see infra Part III.B.

45. See Reid Ewing et al., Growing Cooler: The Evidence on Urban Development and Climate Change 27-31, 35-36 (2008) (providing a comprehensive analysis for reducing vehicle miles traveled in urban areas); Alice Kaswan, Climate Change, Consumption, and Cities, 36 Fordham Urb. L.J. 253, 280-83, 296 (2009) (analyzing the mitigation role of local action on land use, transportation, buildings, 
context for understanding how actions by small suburban cities compare to what is possible under their authority. However, to the extent that leader cities' actions are analyzed in depth in this literature, case examples tend to center on large localities with minimal focus on the variety of little cities that comprise their suburbs and the actions that these cities are taking. ${ }^{46}$

While some of this scholarship considers how suburbs fit into metropolitan efforts to reduce emissions, it tends to treat the suburbs as an undifferentiated mass to be contrasted with the center city. ${ }^{47}$ This literature critiques their unsustainable land use patterns, which result in their comparatively large carbon footprints ${ }^{48}$ and

and energy consumption, and the ways in which federal legislation could support that local role); Katherine A. Trisolini, All Hands on Deck: Local Governments and the Potential for Bidirectional Climate Change Regulation, 62 StAn. L. Rev. 669, 735, 743-45 (2010) (detailing a wide range of local powers relevant to mitigation including regulation of buildings and energy efficiency, zoning and land use power, waste and garbage, and local proprietary functions, and proposing a bidirectional coordination model); Kirsten Engel, State and Local Climate Change Initiatives: What Is Motivating State and Local Governments to Address a Global Problem and What Does This Say About Federalism and Environmental Law?, 38 URB. LAw. 1015, 1023-25 (2006) (exploring what motivates cities to act); Michael Burger, Empowering Local Autonomy and Encouraging Experimentation in Climate Change Governance: The Case for a Layered Regime, 39 EnvtL. L. Rep. 11161, 11164-65 (2009) (considering how economist Charles Tiebout's arguments for the value of interlocal competition interact with local decisionmaking to take action on climate change).

46. See Heike Schroeder \& Harriet Bulkeley, Global Cities and the Governance of Climate Change: What Is the Role of Law in Cities?, 36 Fordham URB. L.J. 313, 351-59 (2009) (comparing the actions of Los Angeles and London); David Dodman, Blaming Cities for Climate Change? An Analysis of Urban Greenhouse Gas Emissions Inventories, 21 Env't \& URbanization 185, 189 tbl.2 (2009) (comparing greenhouse gas emissions of eleven cities in Europe, North America, South America, and Asia); Melissa Powers, U.S. Municipal Climate Plans: What Role Will Cities Play in Climate Change Mitigation?, in Local Climate Change Law: Environmental Regulation in Cities and Other Localities 134 (Benjamin J. Richardson ed., 2012) (comparing several major U.S. cities); Hari M. Osofsky \& Janet Koven Levit, The Scale of Networks?: Local Climate Change Coalitions, 8 CHI. J. InT'L L. 409, 414-15 (2008) (comparing Portland, Oregon and Tulsa, Oklahoma).

47. See, e.g., Ewing Et AL., supra note 45, at 67-73 (exploring ways in which compact development can reduce vehicle miles traveled, with specific examples of suburban efforts included); Edna Sussman et al., Climate Change Adaptation: Fostering Progress Through Law and Regulation, 18 N.Y.U. Envtu. L.J. 55, 109-10 (2010) (discussing efforts by New York suburbs on smart growth, California regional planning, and their implications for adaptation); Dan Tarlock, Fat and Fried: Linking Land Use Law, the Risks of Obesity, and Climate Change, 3 Pittsburgh J. Envtl. Pub. Health L. 31 (2009) (examining how land use strategies could work in both cities and suburbs); Trisolini, supra note 45, at 716 (noting that many of the cities adopting Smart Code were suburbs and exurbs in the South). There have long been more nuanced analyses of suburbs. See, e.g., Darcy Seaver, Conference Explores Older Suburbs as Regional Pivot Points, Nation's Cities Weekly, Feb. 22, 1999, available at http://www.thefreelibrary.com/Conferenc e+Explores+Older+Suburbs+as+Regional+Pivot+Points.-a054032273 (discussing a 1999 conference at the University of Minnesota on first-ring suburbs). However, these are rarely incorporated into the legal literature on suburbs and climate change.

48. For examples of the literature on cities, suburbs, and sustainable land use, see John R. Nolon, The Land Use Stabilization Wedge Strategy: Shifting Ground to Mitigate Climate Change, 34 WM. \& Mary Envtu. L. \& Pol'y Rev. 1, 3 n.16, 8-9 (2009) (citing Ewing ET AL., supra note 45) (relying on Ewing's claim that Chicago citizens drive fewer than 21,000 miles, compared with nearly 30,000 in suburban Chicago County, and emit $80 \%$ fewer tons of carbon dioxide per household than do suburbanites in the surrounding county, and further exploring strategies urban areas can use to reduce their carbon 


\section{THE GEOGRAPHY OF SOLVING GLOBAL ENVIRONMENTAL PROBLEMS}

perpetuate racial segregation. ${ }^{49}$ These analyses are dominated by discussion of controversies over how to address sprawl or approach smart growth. ${ }^{50}$

An emerging interdisciplinary literature on metropolitan emission patterns and reduction strategies takes a similar approach; often with great spatial sophistication, it maps broad emissions patterns in the suburbs that generally do not differentiate among the varying types of little cities that comprise them. ${ }^{51}$ For example, one of the

footprints); J.B. Ruhl, Taming the Suburban Amoeba in the Ecosystem Age: Some Do's and Don'ts, 3 Widener L. Symp. J. 61, 75, 78-86 (1998) (using contested suburban development in Austin, Texas as a starting point for proposing ten principles for law's role in sustainable suburban development); Patricia E. Salkin, Sustainability and Land Use Planning: Greening State and Local Land Use Plans and Regulations to Address Climate Change Challenges and Preserve Resources for Future Generations, 34 WM. \& MARY Envtl. L. \& Pol'y Rev. 121, 124-25 (2009) (exploring a variety of approaches that state and local governments can take to increase sustainability and mitigate climate change).

49. For examples of articles looking at the nexus of suburbs, racial segregation, and climate change, see Kaswan, supra note 45 (exploring the land use measures that might address the city-suburb divide and reduce vehicle miles traveled, the barriers to implementing such measures, the role for federal measures, and the need to integrate the socioeconomic and environmental concerns in local land use planning); James A. Kushner, Affordable Housing as Infrastructure in the Time of Global Warming, 42/43 URB. LAw. $179,182,197-200$ (2011) (presenting a vision of smart growth that would address climate change and segregation simultaneously); Bekah Mandell, Racial Reification and Global Warming: A Truly Inconvenient Truth, 28 B.C. Third World L.J. 289, 304-05, 335-43 (2008) (exploring the way in which citysuburb segregation contributes to climate change); Florence Wagman Roisman, Sustainable Development in Suburbs and Their Cities: The Environmental and Financial Imperatives of Racial, Ethnic, and Economic Inclusion, 3 Widener L. Symp. J. 87 (1998) (exploring the role of racial and ethnic segregation in undermining sustainability).

50. For a few interesting examples of the voluminous literature on sprawl, see William W. Buzbee, Urban Sprawl, Federalism, and the Problem of Institutional Complexity, 68 Fordham L. Rev. 57 (1999) (exploring the multilevel governance challenges of addressing sprawl and the potential role for conditional federal funding in ameliorating it); Reid Ewing \& Fang Rong, The Impact of Urban Form on U.S. Residential Energy Use, 19 Housing Pol'y Debate 1 (2008) (analyzing the way in which urban form impacts residential energy use); Christine A. Klein, The New Nuisance: An Antidote to Wetland Loss, Sprawl, and Global Warming, 48 B.C. L. Rev. 1155 (2007); Christian Iaione, The Tragedy of Urban Roads: Saving Cities from Choking, Calling on Citizens to Combat Climate Change, 37 Fordham Urb. L.J. 889 (2009); Nicole Stelle Garnett, Save the Cities, Stop the Suburbs?, 116 Yale L.J. 598 (2006) (reviewing books published in 2005 about debates over urban-growth restrictions); Alexandra Lampert, California's Fight Against Global Warming: Finally Getting Smart About Sprawl?, 20 Stan. L. \& Pol'y Rev. 193 (2009) (describing California's Senate Bill 375, which was signed into law in 2008, as a small step forward); Mary D. Nichols, Sustainable Communities for a Sustainable State: California's Efforts to Curb Sprawl and Cut Global Warming Emissions, 12 Vт. J. Envtl. L. 185 (2010) (discussing California’s Senate Bill 375 as an example of metro-regional land use planning approaches); J.B. Ruhl \& James Salzman, Climate Change, Dead Zones, and Massive Problems in the Administrative State: A Guide for Whittling Away, 98 Calif. L. Rev. 59 (2010) (discussing complexity of understanding and addressing sprawl).

51. For examples of metropolitan-focused analyses in climate change mitigation, see Marilyn A. Brown et al., Shrinking the Carbon Footprint of Metropolitan America, in Blueprint for American Prosperity: Unleashing the Potential of a Metropolitan Nation 6-11 (Brookings Inst. Metro. Policy Program 2008) (arguing that federal policy leadership is needed to complement state and local efforts on metropolitan emissions); Patrick M. Condon et al., Urban Planning Tools for Climate Change Mitigation 20-42 (Lincoln Inst. of Land Policy 2009) (exploring, as illustrated through case studies, the ways various modeling tools can help in the planning process to reduce carbon footprints of new development); Yonn Dierwechter, Metropolitan Geographies of US Climate Action: Cities, Suburbs, and the Local Divide in Global Responsibilities, 12 J. Envtl. Pol'y \& Plan. 59 (2010) (considering city-suburb 
more nuanced of such analyses, by urban studies professor Yonn Dierwechter, engages in sophisticated mapping of local climate change action in six major metropolitan regions to explore the patterns of climate change action and identify what motivates behavior. ${ }^{52}$ Using participation in the Mayors Agreement as a proxy for activity on climate change and situating itself in the broader context that only about $5 \%$ of cities nationwide participate in this agreement, this study finds that substantial climate change action in the central cities did not spread adequately into the suburbs, and argues for larger-scale mandates to address "a massive implementation gap." 33 However, its analysis considered neither the characteristics of the suburbs taking action nor how climate change action varied across the different types of cities that make up a metropolitan region. ${ }^{54}$ Similarly, a policy brief by economists Edward Glaeser and Matthew Kahn compares emissions patterns across metropolitan areas. ${ }^{55}$ The brief explores the differences between city-suburb emission dynamics in older East Coast cities such as Boston (where suburban emissions are higher than in central cities, but level off after ten miles) and the West Coast city of Los Angeles (where suburban emissions are lower than in the central city). ${ }^{56}$ But Glaeser and Kahn's interesting mapping did not differentiate among the suburban cities by urban type. ${ }^{57}$

The basis for a more detailed look inside suburbs engaging in climate change action exists, however, because of the emerging scholarly literature exploring the nuances of the cities that make up suburbs. Law professor Myron Orfield, sometimes in collaboration with urban studies scholar Thomas Luce, has been an important pioneer in this type of spatial-legal analysis. Using geographic information system technology together with demographic data, Orfield has produced detailed maps that provide a clearer understanding of the very different types of suburbs that make up major U.S. cities. ${ }^{58}$ Based on this data, Orfield has classified the different types of

dynamics of six U.S. metropolitan regions, but without detailed comparison of the individual suburban cities); Edward L. Glaeser \& Matthew Kahn, The Greenness of Cities (2008), available at http://www.hks.harvard.edu/var/ezp_site/storage/fckeditor/file/pdfs/centers-programs/centers/ taubman/policybriefs/greencities_final.pdf (exploring variations in metropolitan emissions patterns across metropolitan areas and the differences between city-suburb dynamics). For an example of a study focusing purely on suburban action, see Sarah E. Knuth, Addressing Place in Climate Change Mitigation: Reducing Emissions in a Suburban Landscape, 30 Applied Geography 518, 520 (2010) (providing a case study of efforts to develop a climate change mitigation plan in a wealthy suburban county).

52. Dierwechter, supra note 51, at 66-67.

53. Id. at 60,80 .

54. See id.

55. See Glaeser \& Kahn, supra note 51, at 1-3, 7-8.

56. See id.

57. See id.

58. The maps in question are identified as "1-1" and "2-1" in Myron Orfield, American Metropolitics: The New Suburban Reality (2002). According to leading geographic information system company Esri, "A geographic information system (GIS) integrates hardware, software, and data for capturing, managing, analyzing, and displaying all forms of geographically referenced information." What Is GIS?, EsRI, http://www.esri.com/what-is-gis/overview\#overview_panel (last visited Mar. 29, 2014). 


\section{THE GEOGRAPHY OF SOLVING GLOBAL ENVIRONMENTAL PROBLEMS}

suburbs that surround center cities into several categories: stressed, developed job centers, affluent residential, developing job centers, and bedroom developing. ${ }^{59}$ Moreover, Orfield's work is part of a broader literature in geography and urban studies that examines the nuances of the cities that make up suburbs and how they are evolving. ${ }^{60}$ Part IV's case study of the Twin Cities metropolitan region models how this data can be brought together with an examination of climate change efforts within particular suburban cities to provide a more nuanced analysis of where possibilities for suburban action lie. ${ }^{61}$

\section{B. Locating Suburbs in Multilevel Networks and Pluralist/Polycentric Governance Approaches}

An analysis of suburban climate action focused simply on the actions of particular leader suburbs and their demography would be incomplete, however, without an exploration of their interactions with multilevel networks and legal efforts to address climate change. Local action on climate change takes place in a broader context of debates over international, national, and state action. An extensive scholarly literature across many disciplines explores the role of networks in governance. Much of this discourse occurs in relatively isolated streams. One stream, at the intersection of international law, international relations, and transgovernmentalism, examines relationships among a range of governmental and nongovernmental entities and the ways in which they shape international governance. International legal scholar AnneMarie Slaughter's $A$ New World Order, for instance, provides a vision of an international and transnational system comprised of vertical and horizontal networks of governmental officials interacting with each other and with disaggregated international organizations. ${ }^{62}$ Another stream at the intersection of urban studies and geography examines transnational interactions among world cities and their implications. Sociologist Saskia Sassen, for example, has explored the ways in which economic globalization and the emergence of new information and communication technologies have made world cities key nodes for cross-border networks and resource concentration. ${ }^{63}$

59. See Orfield, supra note 58 , at $46-48$.

60. For examples of thoughtful analyses of the changing nature of suburbs and metropolitan regions, see $i d$. See also Twenty-First Century Gateways: Immigrant Incorporation in Suburban America (Audrey Singer et al. eds., 2008).

61. See infra Part IV.

62. Anne-Marie Slaughter, A New World Order 18-23 (2005).

63. See Saskia Sassen, Locating Cities on Global Circuits, in Global Networks, Linked Cities 1, 28-31 (Saskia Sassen ed., 2002). For additional analyses of the role of cities in a globalizing world, see NeIL Brenner, New State Spaces: Urban Governance and the Rescaling of Statehood (2004); Nat'l Research Council, Cities Transformed: Demographic Change and its Implications in the Developing World (Mark R. Montgomery et al. eds., 2003); Globalizing Cities: A New Spatial Order? (Peter Marcuse \& Ronald van Kempen eds., 2000); Heidi H. Hobbs, City Hall Goes Abroad: The Foreign Policy of Local Politics (1994); Saskia Sassen, The Global City: New York, London, Tokyo (2d ed. 2001); H.V. Savitch \& Paul Kantor, Cities in the International Marketplace: The Political Economy of Urban Development in North America and 
A related approach in the geography scale literature considers whether different governmental levels are themselves networks, with Professor Kevin Cox arguing that local spaces are comprised both of core local interactions and multilevel ones. ${ }^{64}$ At the law and anthropology intersection, Professor Annelise Riles has examined the operation of multilevel networks in the context of Fijian activists and bureaucrats preparing for and then participating in the U.N. Fourth World Conference on Women. ${ }^{65}$ While each of these accounts is distinct in its focus and orientation, a common thread running through these literatures is their analyses of the ways in which interactions at multiple levels outside of the formal strictures of law-formation help to constitute governance, whether we call it law or not, and the ever-more-important role of cities in those dynamics.

Of most relevance to the current topic, scholarship has explored the potential governance role of multilevel subnational climate change networks. Professor Judith Resnik, Joshua Civin, and Joseph Frueh have examined the wide range of subnational networks working on climate change and argued that these networks could play a constructive role in shaping federal policy. ${ }^{66}$ Professor Janet Levit and I have considered the way in which bottom-up networking among cities could contribute to international efforts to address climate change. ${ }^{67} \mathrm{I}$ also have explored the role played by transnational networks of cities, states, and provinces in the negotiations that occurred during the 2009 U.N. Climate Change Conference in Copenhagen, Denmark, and queried how these networks could be integrated into the treaty process. ${ }^{68}$ These analyses provide pathways for thinking about the current and potential international and national legal significance of networks among cities working to address climate change, either through formal legal reform or through expanded recognition of such networks' capacity to influence those formal processes.

Another largely separate stream of scholarship about pluralist or polycentric climate change governance complements this discourse about subnational climate

Western Europe (2002); Richard Sennett, The Conscience of the Eye: The Design and Social Life of Cities (1990); Spaces of Globalization: Reasserting the Power of the Local (Kevin R. Cox ed., 1997); World Cities in A World-System (Paul L. Knox \& Peter J. Taylor eds., 1995); Gerald E. Frug \& David J. Barron, International Local Government Law, 38 URb. Law. 1 (2006).

64. See Kevin R. Cox, Spaces of Dependence, Spaces of Engagement and the Politics of Scale, or: Looking for Local Politics, 17 Pol. Geography 1, 2 (1998). For other scholarship interacting with Cox's approach, see Katherine T. Jones, Scale as Epistemology, 17 Pol. Geography 25 (1998); Dennis R. Judd, The Case of the Missing Scales: A Commentary on Cox, 17 Pol. Geography 29 (1998); Michael Peter Smith, Looking for the Global Spaces in Local Politics, 17 Pol. Geography 35 (1998); Lynn A. Staeheli, Globalization and the Scales of Citizenship, 19 Geography Res. F. 60 (1999). For Cox's response to some of that scholarship, see Kevin R. Cox, Representation and Power in the Politics of Scale, 17 Pol. Geography 41 (1998).

65. See Annelise Riles, The Network Inside Out (2000) (providing an anthropological account of networks that includes in-depth engagement of sociolegal spaces at multiple levels).

66. See Judith Resnik et al., Ratifying Kyoto at the Local Level: Sovereigntism, Federalism, and Translocal Organizations of Government Actors (TOGAS), 50 Ariz. L. Rev. 709, 726-33, 764 (2008).

67. Osofsky \& Levit, supra note 46, at 412-14.

68. See Osofsky, supra note 27 , at 67 ; $c f$. Osofsky, supra note 3 (exploring climate change as a multiscalar regulatory problem). 


\section{THE GEOGRAPHY OF SOLVING GLOBAL ENVIRONMENTAL PROBLEMS}

change networks. Although a rich scholarly literature has existed for a number of years on various aspects of multilevel climate change governance, Nobel Prizewinning economist Elinor Ostrom's 2009 World Bank policy research working paper-arguing for polycentric approaches to climate change- has helped spur greater interest in developing governance models that recognize the relevance of a wide range of formal and informal action beyond the confines of the UNFCCC. ${ }^{69}$ After extensive discussion - mostly focused on major cities - of why smaller-scale action, including that of individual cities and networks of localities, can serve as an important part of addressing this collective action problem, Ostrom's working paper concludes:

Given the complexity and changing nature of the problems involved in coping with climate change, there are no "optimal" solutions that can be used to make substantial reductions in the level of greenhouse gases emitted into the atmosphere. A major reduction in emissions is, however, needed. The advantage of a polycentric approach is that it encourages experimental efforts at multiple levels, as well as the development of methods for assessing the benefits and costs of particular strategies adopted in one type of ecosystem and comparing these with results obtained in other ecosystems. A strong commitment to finding ways of reducing individual emissions is an important element for coping with climate change. Building such a commitment, and the trust that others are also taking responsibility, can be more effectively undertaken in small- to medium-scale governance units that are linked through information networks and monitoring at all levels. ${ }^{70}$

Ostrom's analysis helps pave a way for better conceptualization of the role of cities, even very small ones, in multilevel climate change governance because it treats the international treaty negotiations as just one piece of a complex puzzle. ${ }^{71} \mathrm{In}$ particular, it focuses on the ways in which small-scale governments can help build the trust and commitment needed to overcome collective action failures, a function that arguably can be performed more effectively in the small cities of the suburbs than in the larger center cities, where there are many more constituencies by virtue of their greater size. ${ }^{72}$

69. See Elinor Ostrom, A Polycentric Approach for Coping with Climate Change (The World Bank, Policy Research Working Paper No. 5095, 2009), available at http://www.iadb.org/intal/intalcdi/ pe/2009/04268.pdf. For an example of scholarship building on this approach, see Daniel H. Cole, From Global to Polycentric Climate Governance, (European Univ. Inst. Robert Schuman Ctr. for Advanced Studies, Working Paper No. 2011/30, 2011), available at http://cadmus.eui.eu/handle/1814/17757.

70. Ostrom, supra note 69 , at 39.

71. See id. at 35 .

72. See id. at 33-35. 
Ostrom's polycentric model has much in common with pluralist approaches, ${ }^{73}$ which in turn have commonalities with the New Haven School, ${ }^{74}$ in that they all treat a diverse set of activity as relevant to lawmaking. Under such models, activities by multilevel networks of cities, some of which are suburbs, to spur more local, state, national, and international mitigation efforts can be considered as part of a lawmaking process that also includes the formal treaty processes and accompanying national legislation and regulation. ${ }^{75}$ Other streams of scholarship, like new governance, ${ }^{76}$ regulatory institutions theory, ${ }^{77}$ and adaptive management, ${ }^{78}$ explore mechanisms for

73. Global legal pluralism examines the multiple normative, and sometimes legal, communities operating in shared social space and the implications of having simultaneous valid orders. For examples of this approach in a variety of substantive contexts, see Paul Schiff Berman, Global Legal Pluralism, 80 S. CAL. L. Rev. 1155 (2007); Robert B. Ahdieh, Dialectical Regulation, 38 Conn. L. Rev. 863 (2006); Diane Marie Amann, Abu Ghraib, 153 U. PA. L. Rev. 2085 (2005); Janet Koven Levit, A Bottom-Up Approach to International Lawmaking: The Tale of Three Trade Finance Instruments, 30 YALE J. INT'L L. 125 (2005); Ralf Michaels, The Re-state-ment of Non-State Law: The State, Choice of Law, and the Challenge from Global Legal Pluralism, 51 Wayne L. Rev. 1209 (2005); William W. Burke-White, International Legal Pluralism, 25 Мich. J. Int'L L. 963 (2004); Diane Marie Amann, Calling Children to Account: The Proposal for a Juvenile Chamber in the Special Court for Sierra Leone, 29 Pepr. L. Rev. 167 (2001); Elena A. Baylis, Parallel Courts in Post-Conflict Kosovo, 32 Yale J. Int'L L. 1 (2007). I have examined pluralism in the context of climate change litigation in Hari M. Osofsky, Climate Change Litigation as Pluralist Legal Dialogue?, 26 Stan. Envtl. L.J. 181 (2007).

74. The New Haven School treats law as "a process of authoritative decision by which the members of a community clarify and secure their common interests." 1 Harold D. Lasswell \& Myres S. McDougal, Jurisprudence for a Free Society: Studies in Law, Science and Policy, at xxi (1992); accord Myres S. McDougal et al., The World Community: A Planetary Social Process, 21 U.C. Davis L. Rev. 807, 810-11 (1988). For a discussion of the New Haven School's goals, see Lasswell \& McDougal, supra, at xxix.

75. See Osofsky, supra note 73, at 184.

76. For examples of new governance scholarship, see Ruhl \& Salzman, supra note 50; LAw ANd New Governance in the EU and US (Gráinne de Búrca \& Joanne Scott eds., 2006); Orly Lobel, The Renew Deal: The Fall of Regulation and the Rise of Governance in Contemporary Legal Thought, 89 Minn. L. Rev. 342, 371-76 (2004); Bradley C. Karkkainen, Reply, "New Governance" in Legal Thought and in the World: Some Splitting as Antidote to Overzealous Lumping, 89 Minn. L. Rev. 471, 471-80 (2004); Orly Lobel, Surreply, Setting the Agenda for New Governance Research, 89 Minn. L. Rev. 498, 498-99 (2004).

77. For examples of scholarship from the Regulatory Institutions Network at Australian National University, see Charlotte Wood et al., Applications of Responsive Regulatory Theory in Australia and Overseas (Regulatory Institutions Network, Occasional Paper No. 15, 2010), available at http://vab.anu. edu.au/pubs/Responsive\%20Regulation_June\%202010.pdf; Valerie Braithwaite, Ten Things You Need to Know About Regulation but Never Wanted to Ask (Regulatory Institutions Network, Occasional Paper No. 10, 2006), available at http://pandora.nla.gov.au/pan/67415/20080123-0746/ctsi.anu.edu.au/ publications/10thingswhole.pdf.

78. "Adaptive management" at times draws from concepts of panarchy. See C.S. Holling et al., In Quest of a Theory of Adaptive Change, in Panarchy: Understanding Transformations in Human and Natural Systems 3, 5 (Lance H. Gunderson \& C.S. Holling eds., 2002). It explores how law can be structured to allow for regulatory evolution in response to change. See Alejandro E. Camacho, Assisted Migration: Redefining Nature and Natural Resource Law Under Climate Change, 27 YALE J. on Reg. 171, 171-72 (2010); Robin Kundis Craig, "Stationarity is Dead"-Long Live Transformation: Five Principles for Climate Change Adaptation Law, 34 Harv. Envtl. L. Rev. 9, 17-18 (2010); Michael Ilg, Complexity, Environment, and Equitable Competition: A Theory of Adaptive Rule Design, 41 Geo. J. Int'L L. 647, 650-58 (2010); J.B. Ruhl \& Robert L. Fischman, Adaptive Management in the Courts, 95 Minn. L. Rev. 


\section{THE GEOGRAPHY OF SOLVING GLOBAL ENVIRONMENTAL PROBLEMS}

creating more inclusive, responsive, decentralized governance. In the U.S. domestic law context, an extensive and rapidly growing dynamic federalism literature complements this scholarship through its analysis of how to structure appropriate and effective multilevel governance structures. ${ }^{79}$

Together, these approaches provide fruitful ground for conceptualizing practical ways to leverage multilevel networks of cities-and leader suburbs' participation in them-to make important incremental progress in mitigating climate change. Building on my prior work on multilevel climate change and environmental governance, which draws from these diverse streams of theory, Part IV considers how the participation of small suburban cities in multilevel networks can be used as a mechanism for spurring needed action on climate change, especially at a time when critical larger-scale formal processes remain stalled. It analyzes the potential dual roles of these networks in fostering greater suburban participation and in influencing larger-scale formal processes.

\section{SUBURBS' ROLE IN PLURALIST POLYCENTRIC CLIMATE CHANGE GOVERNANCE}

This Part uses the Twin Cities metropolitan region as a laboratory for analyzing the complexities of integrating small local governments into a polycentric model for addressing climate change. It considers how suburban positionality and participation in multilevel networks influences cities' approaches to climate change.

The Part begins with an overview of the Twin Cities metropolitan region, how the twelve example cities were selected, and their demographic characteristics. It then groups those cities by the type of suburb that they are-stressed city, developed job center, developing job center or bedroom community — to examine the extent to which cities' demographic characteristics shape the types of mitigation initiatives that they choose to pursue. The Part next examines the participation of the sample cities in state, regional, national, and international networks; the ways in which those networks are interacting; and how they might be used to encourage greater participation. It then considers the extent to which these voluntary networks are integrated with formal governance approaches and opportunities for creating additional synergies. It concludes by making proposals for next steps in both research and action.

The sample cities provide promising examples of what is possible for different types of suburbs and how differentiated analysis might help to shape strategies for including them as part of an approach to addressing climate change that is both pluralist and polycentric. But a core challenge remains: operationalizing the suburban capacity for mitigation at a time when international and national efforts at a comprehensive solution are stymied and few state governments are requiring their

424, 436-40 (2010); J.B. Ruhl, Law's Complexity: A Primer, 24 GA. ST. U. L. Rev. 885, 890-901 (2008); Sandra Zellmer, Essay, A Tale of Two Imperiled Rivers: Reflections from a Post-Katrina World, 59 FLA. L. Rev. 599, 627-30 (2007); Bradley C. Karkkainen, Information-Forcing Environmental Regulation, 33 Fla. St. U. L. Rev. 861, 884-88 (2006).

79. I have provided an extensive summary and synthesis of this literature in the context of climate change in Osofsky, supra note 23. See also Kirsten H. Engel, Harnessing the Benefits of Dynamic Federalism in Environmental Law, 56 ЕмоRу L.J. 159, 160 (2006). 
cities to take steps on climate change. ${ }^{80}$ This Part focuses on that challenge and considers the role that multilevel voluntary networks-paired with other existing regional, state, national, and international institutions-might play in broadening and deepening suburban participation and connecting suburban activity with largerscale climate change negotiations.

This analytical approach highlights two important aspects of developing effective approaches that are both pluralist and polycentric. First, simply having more efforts in different settings, especially if modeled for similarly situated suburbs, is itself a part of this strategy. The resulting emissions reductions in these communities, to the extent that they are meaningful and do not simply shift emissions, help achieve mitigation. ${ }^{81}$ Second, increasing linkages between this multiplicity of efforts provides opportunities for additional mitigation gains. Not only can coordination (and perhaps even interaction) improve efficiency and eliminate redundancy, but it also provides opportunities for mutual pressure and learning. ${ }^{82}$ This Part explores both of these aspects in the context of these suburbs' involvement in multilevel networks and bases its proposals on them.

\section{A. Twin Cities Suburban Action as a Case Study}

As noted in the introduction, the Twin Cities metropolitan region is highly fragmented, has significant regional governance, and its central cities have leading mitigation efforts. ${ }^{83}$ Orfield and Luce's in-depth study of the Twin Cities documents that the region contains 172 cities and ninety-seven townships, and ranks as the fifth most fragmented among the United States' fifty largest metropolitan areas. ${ }^{84}$ Like most major metropolitan areas, jobs and population have decentralized significantly over the last thirty years, with current growth concentrated in the outer suburbs; for example, from 1990 to 2004, Minneapolis grew at 1.3\% and Saint Paul grew at $3.0 \%$, as compared to the region's overall growth rate of $22.5 \% .{ }^{85}$ As this growth has occurred, suburban differentiation has taken place, with some suburbs, especially inner ones, increasingly reflecting the fiscal stresses and racial and poverty concentrations of the central cities, and other suburbs, especially outer ones, facing the complexities of rapid growth with inadequate infrastructure. ${ }^{86}$ Only a small percentage of the region's suburban cities fit the traditional model of wealthy residents who commute into the central city. ${ }^{87}$

80. See Lazarus, supra note 4 and accompanying text.

81. See supra Part III.A.

82. See supra Part III.B.

83. See Myron Orfield \& Thomas F. Luce Jr., Region: Planning the Future of the Thin Cities xiii-xiv (2010). By "fragmentation," Orfield and Luce are referring to the large number of separate local government entities in the region. $I d$.

84. Id. at 2 .

85. Id. at 14 .

86. Id. at $43-49$.

87. Id. at 46 . 
Figure 1: Map of Cities in the Twin Cities Metropolitan Region by Category ${ }^{88}$

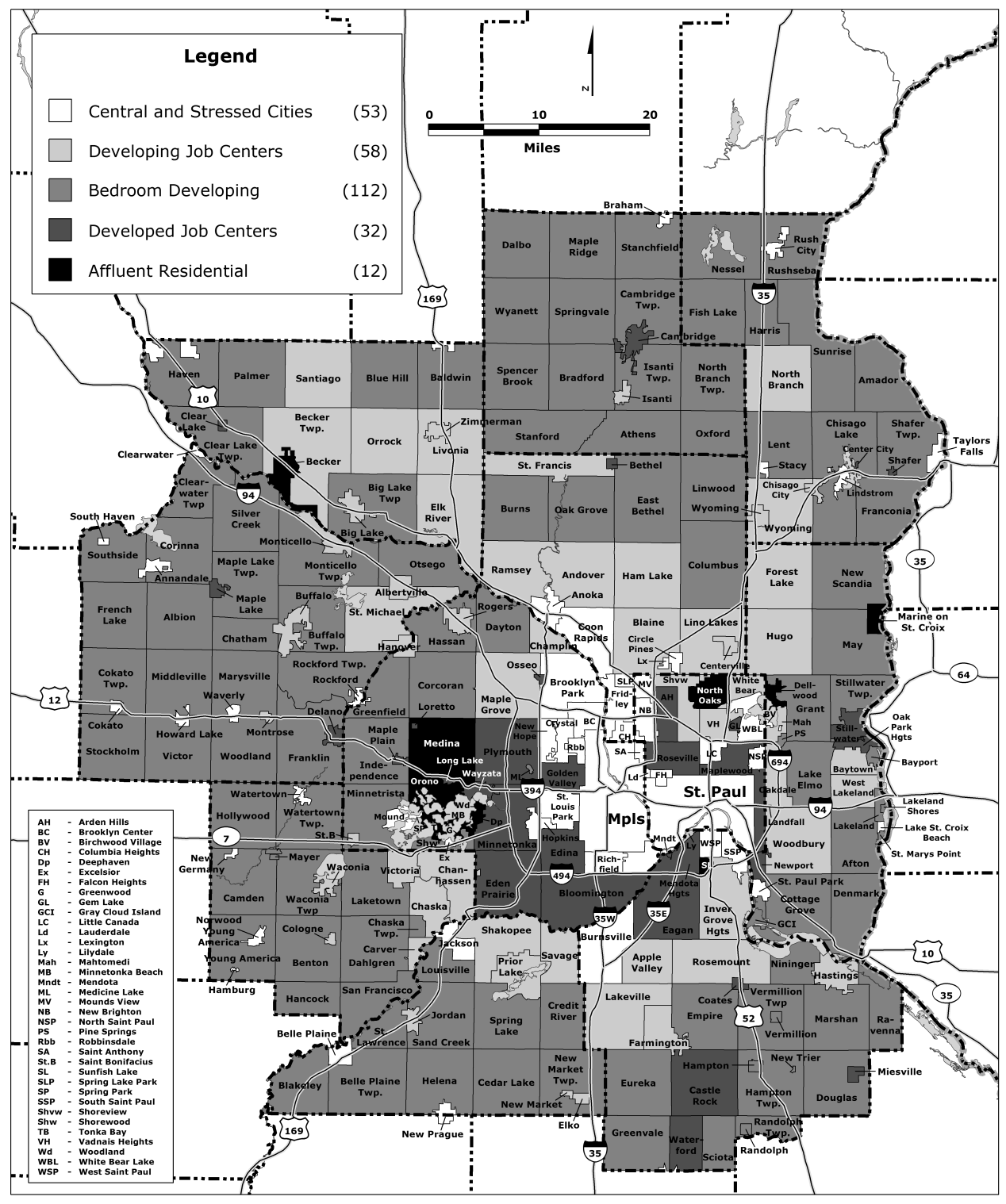

88. Id. at 44 (reproduced with the permission of Myron Orfield). 
The distribution of the Twin Cities' approximately 3.1 million residents, as depicted in Figure 1, is: $24 \%$ in the two central cities, $23 \%$ in the fifty-three stressed suburbs, $25 \%$ in the fifty-eight developing job centers, $8 \%$ in the 112 bedroom developing communities, $19 \%$ in the thirty-two developed job centers, and $1 \%$ in the twelve affluent residential communities. ${ }^{89}$

These demographic patterns highlight how important it is for smaller suburban cities to take action on climate change if metro-regional emissions reduction initiatives are to succeed. The two center cities, Minneapolis and Saint Paul, have been national and international leaders on climate change since the early 1990s, joining the International Council for Local Environmental Initiatives (ICLEI) in 1992 and cofounding its Cities for Climate Protection Campaign in 1993. ${ }^{90}$ Since pioneering one of the first local greenhouse gas emissions reduction plans in the country, they have consistently had aggressive reduction goals and have received national recognition for their innovative efforts on climate change. ${ }^{11}$ However, these significant initiatives by Minneapolis and Saint Paul-even taking into account the suburban residents who work in those central cities-only address a small fraction of the metropolitan region's emissions.

Few metropolitan regions have developed regional governance structures to the extent that the Twin Cities one has. ${ }^{92}$ Minnesota's experiment in regional governance began in 1967, when its legislature established the Met Council to meet new federal requirements for regional governance; ${ }^{93}$ as of January 2012, the Met Council listed 183 communities in its seven-county metro area. ${ }^{94}$ This entity was intended to build upon decades of ad hoc collaboration among the cities and to address concerns over land use planning, wastewater coordination, and transit funding. ${ }^{95}$ The state legislature gradually expanded the Met Council's powers over time, and the Met Council has played, and continues to play, a significant role in regional planning, including growth management. ${ }^{96}$

89. See id. at $2-3,45$.

90. See Plan: International Council for Local Environmental Initiatives (ICLEI), Saint Paul Minn., http:// www.stpaul.gov/index.aspx?NID=464 (last visited Mar. 29, 2014) [hereinafter Saint Paul ICLEI Plan]; U.S. Envtl. Prot. Agency, Twin Cities Trim Climate Change (1998), available at http://nepis. epa.gov/Adobe/PDF/40000PQ6.pdf.

91. See Minneapolis-Saint Paul Urban CO Project Plan, A Framework for Developing Strategies to Reduce $\mathrm{CO}_{2}$ Emissions, Save Taxes, and Save Resources (1993), available at http://www. minneapolismn.gov/www/groups/public/@citycoordinator/documents/webcontent/convert_284899.pdf; Saint Paul ICLEI Plan, supra note 90; Minneapolis Climate Action Plan, City of Minneapolis, http:// www.minneapolismn.gov/sustainability/climate/index.htm (last visited Mar. 29, 2014).

92. For other examples of well-developed metropolitan regional governments, see generally GreAter Nashville Regional Council, https://www.gnrc.org/ (last visited Mar. 29, 2014); Metro, http:// www.oregonmetro.gov/ (last visited Mar. 29, 2014) (website for Portland metropolitan region).

93. See Orfield \& Luce JR., supra note 83, at 52-53.

94. List of Community Profiles, Metropolitan Council, http://stats.metc.state.mn.us/profile/list.aspx (last visited Mar. 29, 2014).

95. See Orfield \& Luce JR., supra note 83, at 52-80.

96. See id. 


\section{THE GEOGRAPHY OF SOLVING GLOBAL ENVIRONMENTAL PROBLEMS}

Orfield and Luce argue that while the appointed Met Council has accomplished less than Portland, Oregon's elected regional governing body, in part due to Oregon's more developed statewide comprehensive land use planning system, both Portland and the Twin Cities show less sprawl than would be expected at their level of fragmentation. ${ }^{97}$ These regional-level accomplishments, even if they could be augmented significantly by following Portland's model, provide a context in which appropriately focused, locally based initiatives on climate change could supplement regional mitigation efforts.

Over the course of the last several years, a number of Twin Cities suburbs have begun to join their center cities in local action on climate change. This essay focuses on a subset of those suburbs that were the first twelve to join the Minnesota GreenStep Cities program ${ }^{98}$ in the Twin Cities metropolitan region. Although this program focuses more broadly on sustainability, many of its earliest suburban participants are taking steps on climate change. Examining these participants allows for (1) identification of suburbs that have been willing to commit publicly to sustainability goals, which are often less politically controversial than climate change mitigation goals, ${ }^{99}$ and (2) consideration of what actions they are taking-whether as part of their Minnesota GreenStep Cities participation or separate from it— to reduce their greenhouse gas emissions. ${ }^{100}$

Minnesota GreenStep Cities emerged from the fall 2007 Minnesota Clean Energy Resource Teams' (CERTS) ${ }^{101}$ regional listening sessions around the state regarding community-based energy opportunities and the Next Generation Energy Act of 2007. ${ }^{102}$ The legislature in 2008 directed the Minnesota Pollution Control Agency (MPCA), the Minnesota Department of Commerce's Division of Energy Resources, and CERTS to recommend actions that cities could take as part of a voluntary program to recognize "green star" sustainable cities. ${ }^{103}$ The resulting program, Minnesota GreenStep Cities, which launched in June 2010, focuses on twenty-eight best practices and has three

97. See id.

98. Minnesota GreenStep Cities, Minn. Pollution Control Agency, http://greenstep.pca.state.mn.us/ (last visited Mar. 29, 2014) [hereinafter GreenStep Cities].

99. This ability to focus on less divisive framing is a potentially important concern in a political climate in which the Minnesota State Republicans ousted Public Utility Commission Chair Ellen Anderson in January 2012, in part based on her past leadership as a Democratic state senator on renewable energy legislation. See Jim Ragsdale, Senate Republicans Oust Ellen Anderson as PUC Chair, StarTribune (Jan. 30, 2012, 4:47 PM), http://www.startribune.com/politics/blogs/138357554.html. The November 2012 election brought the Minnesota legislature back under Democratic control. Frederick Melo \& MaryJo Webster, Election 2012: Minnesota, by the Numbers, Was Nearly True Blue, Pioneer Press (Nov. 11, 2012, 12:01 AM), http://www.twincities.com/ci_21978013/election-2012-minnesota-by-numbers-was-nearlytrue. However, deep divisions remain in viewpoints about climate change.

100. See generally GreenStep Cities, supra note 98.

101. See id.; see also Minnesotans Building a Clean Energy Future!, Clean Energy Resource Teams, http:// www.cleanenergyresourceteams.org/ (last visited Mar. 29, 2014) [hereinafter Minnesota CERTS].

102. See generally Minnesota CERTS, supra note 101. Minnesota's Next Generation Energy Act of 2007 is codified at Minn. Stat. § 216H.01-.13 (2014).

103. See GreenStep Cities, supra note 98. 
"steps" depending on how many best practices the participating city has taken; ${ }^{104}$ a guide explains how to get started and how to achieve each step. ${ }^{105}$ A steering committeeconsisting of representatives from the MPCA, Great Plains Institute, ${ }^{106}$ CERTS, Urban Land Institute Minnesota, ${ }^{107}$ League of Minnesota Cities, ${ }^{108}$ Izaak Walton League Minnesota Division, ${ }^{109}$ and the Minnesota Department of Commerce Division of Energy Resources-reviews the program annually. ${ }^{110}$ Businesses and other organizations can sponsor GreenStep Cities awards and receive public recognition for their role in the program. ${ }^{111}$ The program is growing rapidly, with new cities continuing to join. ${ }^{112}$

The twelve GreenStep Cities participants that are the focus of this essay represent a diverse cross-section of Twin Cities suburbs, as summarized in Table $1 .{ }^{113}$

\section{Table 1: Characteristics of Twin Cities Metropolitan Region GreenStep Cities}

\begin{tabular}{|c|c|c|c|c|c|c|}
\hline & Pop. ${ }^{114}$ & $\begin{array}{l}\text { Pop. Change } \\
(1990- \\
2004)^{115}\end{array}$ & $\begin{array}{l}\text { Suburb } \\
\text { Location }^{116}\end{array}$ & $\begin{array}{l}\text { Community } \\
\text { Type }^{117}\end{array}$ & $\begin{array}{l}\text { Household } \\
\text { Tax Capacity } \\
(2004)^{118}\end{array}$ & $\begin{array}{l}\text { Party Preference } \\
\text { (by State Senate } \\
\text { Dist.) }(2006)^{119}\end{array}$ \\
\hline Apple Valley & 49,084 & $+41.3-75.6 \%$ & 3rd Ring (S) & $\begin{array}{l}\text { Developing } \\
\text { Job Center }\end{array}$ & $\begin{array}{l}\$ 2,261- \\
\$ 2,950\end{array}$ & $\begin{array}{l}\text { Leaning R } \\
\text { Volatile }\end{array}$ \\
\hline $\begin{array}{l}\text { Cottage } \\
\text { Grove }\end{array}$ & 34,502 & $+22.5-40.2 \%$ & 2nd Ring (SE) & $\begin{array}{l}\text { Bedroom } \\
\text { Developing }\end{array}$ & $\begin{array}{l}\$ 2,007- \\
\$ 2,254\end{array}$ & $\begin{array}{l}\text { Leaning D } \\
\text { Volatile }\end{array}$ \\
\hline
\end{tabular}

104. Id.

105. Id.

106. See What We Do, Great Plains Inst., http://www.betterenergy.org/ (last visited Mar. 29, 2014).

107. See ULI Minnesota Manifesto, Urb. Land Inst. Minn., http://minnesota.uli.org/contact-us/uli-minnesotamanifesto/ (last visited Mar. 29, 2014).

108. See About the League, League of Minn. Cities, http://www.lmnc.org/page/1/about-the-league.jsp (last visited Mar. 29, 2014).

109. See Who We Are, Minn. Division-Izaak Walton League, http://www.minnesotaikes.org/ (last visited Mar. 29, 2014).

110. See GreenStep Cities, supra note 98.

111. See id.

112. See GreenStep Cities, Minn. Pollution Control Agency, http://greenstep.pca.state.mn.us/allCities.cfm (last visited Mar. 29, 2014) [hereinafter GreenStep Cities List] (listing participating GreenStep cities).

113. Compare id., with Table 1.

114. Population data for the various GreenStep cities can be accessed by clicking the city-specific links found at GreenStep Cities List, supra note 112.

115. See Orfield \& Luce Jr., supra note 83, at 15 map 1.2.

116. These are rough classifications from a map of the Twin Cities Metropolitan Region. See id.

117. See id. at 44 , map 1.17 .

118. See id. at 37 , map 1.14 . The regional average tax capacity was $\$ 2,261$. See id.

119. See id. at 277 , map 7.2 . 
THE GEOGRAPHY OF SOLVING GLOBAL ENVIRONMENTAL PROBLEMS

\begin{tabular}{|c|c|c|c|c|c|c|}
\hline & Pop. ${ }^{114}$ & $\begin{array}{l}\text { Pop. Change } \\
(1990- \\
2004)^{115}\end{array}$ & $\begin{array}{l}\text { Suburb } \\
\text { Location }^{116}\end{array}$ & $\begin{array}{l}\text { Community } \\
\text { Type }^{117}\end{array}$ & $\begin{array}{l}\text { Household } \\
\text { Tax Capacity } \\
(2004)^{118}\end{array}$ & $\begin{array}{l}\text { Party Preference } \\
\text { (by State Senate } \\
\text { Dist.) }(2006)^{119}\end{array}$ \\
\hline Eagan & 65,800 & $+22.5-40.2 \%$ & 2nd Ring (S) & $\begin{array}{l}\text { Developed } \\
\text { Job Center }\end{array}$ & $\begin{array}{l}\$ 2,261- \\
\$ 2,950\end{array}$ & $\begin{array}{l}\text { Leaning D } \\
\text { Volatile }\end{array}$ \\
\hline Eden Prairie & 61,151 & $+41.3-75.6 \%$ & 2nd Ring (SW) & $\begin{array}{l}\text { Developed } \\
\text { Job Center }\end{array}$ & $\begin{array}{l}\$ 3,006- \\
\$ 3,992\end{array}$ & $\begin{array}{l}\text { Leaning R } \\
\text { Volatile }\end{array}$ \\
\hline Edina & 47,941 & $+0.0-11.5 \%$ & 1st Ring (SW) & $\begin{array}{l}\text { Developed } \\
\text { Job Center }\end{array}$ & $\begin{array}{l}\$ 3,006- \\
\$ 3,992\end{array}$ & $\begin{array}{l}\text { Leaning } \mathrm{R} \\
\text { Volatile }\end{array}$ \\
\hline $\begin{array}{l}\text { Falcon } \\
\text { Heights }\end{array}$ & 5,300 & $+0.0-11.5 \%$ & 1st Ring (N) & $\begin{array}{l}\text { Stressed } \\
\text { City }\end{array}$ & $\begin{array}{l}\$ 1,580- \\
\$ 1,986\end{array}$ & Safe D \\
\hline Farmington & 21,086 & $\begin{array}{l}+78.6 \% \text { or } \\
\text { more }\end{array}$ & 3rd Ring (S) & $\begin{array}{l}\text { Developing } \\
\text { Job Center }\end{array}$ & $\begin{array}{l}\$ 2,007- \\
\$ 2,254\end{array}$ & $\begin{array}{l}\text { Leaning } \mathrm{R} \\
\text { Volatile }\end{array}$ \\
\hline Hopkins & 17,481 & $+0.0-11.5 \%$ & 1st Ring (W) & $\begin{array}{l}\text { Stressed } \\
\text { City }\end{array}$ & $\begin{array}{l}\$ 1,580- \\
\$ 1,986\end{array}$ & Safe D \\
\hline Mahtomedi & 7,563 & $+41.3-75.6 \%$ & 2nd Ring (NE) & $\begin{array}{l}\text { Developing } \\
\text { Job Center }\end{array}$ & $\begin{array}{l}\$ 2,261- \\
\$ 2,950\end{array}$ & $\begin{array}{l}\text { Leaning R Party } \\
\text { Line }\end{array}$ \\
\hline Maplewood & 38,018 & $+13.1-22.3 \%$ & 1st Ring (NE) & $\begin{array}{l}\text { Developed } \\
\text { Job Center }\end{array}$ & $\begin{array}{l}\$ 2,261- \\
\$ 2,950\end{array}$ & Safe D \\
\hline Oakdale & 27,378 & $+41.3-75.6 \%$ & 2nd Ring (E) & $\begin{array}{l}\text { Developing } \\
\text { Job Center }\end{array}$ & $\begin{array}{l}\$ 1,580- \\
\$ 1,986\end{array}$ & Safe D \\
\hline St. Anthony & 8,226 & $\begin{array}{l}-34.5- \\
-0.2 \%\end{array}$ & 1st Ring (N) & $\begin{array}{l}\text { Stressed } \\
\text { City }\end{array}$ & $\$ 794-\$ 1,506$ & $\begin{array}{l}\text { Leaning D Party } \\
\text { Line }\end{array}$ \\
\hline
\end{tabular}

While their self-selection into a voluntary program suggests that these cities are likely mitigating more actively than many other small cities in the region, and thus probably unrepresentative of suburban efforts more broadly, they have a wide range of population, recent growth, location, community type, household tax capacity, and political party preference. That diversity, paired with the similarities among the measures these cities are taking to address climate change and achieve sustainability, suggests that they may provide a helpful example of how leader, small city-suburbs can contribute to broader multilevel climate change efforts; the ways in which these local initiatives cross-cut party lines is a particularly hopeful sign at this time of deep division in the United States. Focusing on a statewide sustainability program, even though some leader cities-including the center cities-might choose not to participate in the program because they are too far ahead, ${ }^{120}$ also provides a way to capture efforts by cities that might decide not to opt in to the Mayors Agreement but are taking mitigation efforts under the rubric of sustainability.

These twelve suburbs' greenhouse gas mitigation efforts focus on steps entirely within their local control. Although many of the measures that they are taking potentially pair constructively with regional-level policies to address sprawl and

120. In the fall of 2011, I conducted confidential interviews with people involved in cities active in other multilevel climate change and sustainability networks but not participating in GreenStep Cities. Those interviewed suggested that their cities were choosing not to join GreenStep Cities because its steps were too basic for them given their already extensive work on climate change and sustainability. 
consequently reduce metropolitan vehicle miles traveled, these local initiatives do not center on the regional level or above. Participating suburbs generally began their efforts on climate change and energy, often because of the persuasive efforts of one or a small group of politically active individuals who have the capacity to make a significant difference at that scale, well before the GreenStep Cities program commenced. By the time these cities joined GreenStep Cities, many of them were already members of a number of other networks of cities-described in depth in Part IV.C-operating at different scales. ${ }^{121}$

\section{B. The Impact of City Type on Climate Change Mitigation Efforts}

These twelve suburbs' efforts have a great deal in common with one another. Because they are all cities with the types of powers granted to such units of government, they have similar areas in which they can impact mitigation. Almost all of the cities studied made steps with respect to energy use in buildings and vehicle emissions. The more ambitious of the group also used their zoning and land use powers, and created more comprehensive schemes for energy, environment, and sustainability. Institutional structure seemed to make a difference in this respect. Many of the cities that made the greatest strides had some sort of designated body helping to guide their efforts. Cities that made the effort to obtain university and governmental resources also tended to perform more assessments, create overarching strategies, and engage in more projects.

However, despite these commonalities, there were trends within each of the three groups that could assist targeted efforts to encourage participation by more cities and more action by participating cities. The differences did not seem to follow political affiliation in this group, contrary to what the divided discourse in the United States and Minnesota might suggest. Nor did resource constraints seem to dictate what was possible; although the richest group for the most part had the most extensive plans, many of the cities with the least tax capacity had more developed programs than some of the cities with average tax capacity. Rather, to the extent that these suburbs are representative (which is difficult to know with certainty in a small sample size-as noted above, I am currently working on a broader study of several cities to complement this essay's qualitative analysis), their approaches suggest potential leverage points. ${ }^{122}$

Stressed inner suburbs, also referred to as "at-risk communities," face many of the difficulties of their center cities-poverty and social instability that put great pressure on limited resources-but often without center city resources. These cities include "older suburbs, satellite cities, and newer, lower density communities with relatively high poverty rates." 123 They often become poor faster than their center cities because

121. See infra Part IV.C.

122. For a more detailed discussion of each of the twelve suburbs' activities, see Hari M. Osofsky, Suburban Climate Change Efforts: Possibilities for Small and Nimble Cities Participating in State, Regional, National, and International Networks, 22 Cornell J.L. \& Pub. Pol'y 395 (2012).

123. Orfield, supra note 58, at 36. 


\section{THE GEOGRAPHY OF SOLVING GLOBAL ENVIRONMENTAL PROBLEMS}

they lack business districts as well as urban resources such as public infrastructure, cultural attractions, parks, and other amenities. ${ }^{124}$

The Twin Cities' stressed inner suburbs, including the three cities studiedFalcon Heights, Hopkins, and Saint Anthony-follow this pattern. They have below average household tax capacity and growth compared to the other suburbs, with Saint Anthony poorer and growing more slowly than the other two. Politically, they are the most liberal group of cities in this sample; like their center cities, they all lean or are solidly Democratic in their voting patterns. These suburbs' greater economic stresses influence their approach to climate change and sustainability. Their efforts have to be particularly sensitive to economics and up-front costs and often include an urban redevelopment component. ${ }^{125}$

Developed job centers are not simply relatively affluent bedroom communities within commuting distance of central cities, but rather have become important players in their regional economies. ${ }^{126}$ They have comparatively large tax bases but support less of the social costs of poverty than their central cities. As a result, they suffer fewer of the stresses of the central cities and inner suburbs described above. ${ }^{127}$

The four developed job centers participating in GreenStep Cities-Eagan, Eden Prairie, Edina, and Maplewood-fit this profile. They all have an above average tax base, with Eden Prairie and Edina having the highest tax base of the sample. They vary in their growth rate, however, with the first-ring developed job centers growing more slowly than their second-ring counterparts. They are much more politically diverse and volatile than the inner stressed suburbs studied, with two tending Democratic and two tending Republican. This diversity suggests some hope for the bipartisan character of potential mitigation measures in this critical group of established and affluent suburbs despite the broader political divisions over climate change in the United States and Minnesota. ${ }^{128}$

These cities collectively have the most extensive programs in the sample. Each of these developed job centers has made significant steps in the major areas in which cities can take action. They all participate in the Mayors Agreement and have made commitments in the Copenhagen City Climate Catalogue. ${ }^{129}$ Eden Prairie has even received national recognition from the Mayors Agreement in the small city category. ${ }^{130}$ In their assessment and implementation, these cities have been skillful at

124. Id. at $33-36$.

125. I discuss this topic in further detail in Osofsky, supra note 122.

126. See Orfield \& Luce JR., supra note 83, at 46.

127. See id.; see also OrFIELD, supra note 58, at 44-46.

128. See supra Table 1.

129. City Climate Catalogue to Influence International Climate Negotiations, ICLEI, http://archive.iclei.org/ index.php?id=9425\&no_cache=1\&tx_ttnews[tt_news]=3524\&tx_ttnews[backPid] $=9426 \& \mathrm{cHash}=\mathrm{c} 45$ $18 \mathrm{~d} 4364$ (last visited Mar. 29, 2014).

130. See Mayors Climate Prot. Ctr., Taking local Action: Mayors and Climate Protection Best Practices 13 (2011) [hereinafter MCPC Best Practices], available at http://usmayors. org/79thAnnualMeeting/documents/BestPractices2011ClimateAwardWinners.pdf. 
taking advantage of university and governmental resources, but also have the fiscal capacity to make up-front investments that will pay off over time.

Developing job centers and bedroom developing communities are rapidly growing cities toward the edge of a metropolitan region that have roughly average tax capacity. ${ }^{131}$ The main difference between these two groups is that bedroom developing communities lack the job concentrations of developing job centers and are farther from the center cities. ${ }^{132}$ In both groups, tax capacity does not easily match the new costs resulting from high growth rates. ${ }^{133}$ From a climate change perspective, their growth rates present both a challenge and an opportunity. They are evolving more rapidly than other categories of suburban cities and are consequently making choices that impact their carbon footprints. As a result, their land use and emissions patterns are often more malleable than those of more developed suburbs closer to the center cities. ${ }^{134}$ However, these edge cities also tend to sprawl and have limited resources to address these patterns. ${ }^{135}$

The five Twin Cities metropolitan region developing job centers and bedroom developing communities participating in GreenStep Cities-Apple Valley, Cottage Grove, Farmington, Mahtomedi, and Oakdale-fit this profile. These cities' populations all grew by more than $40 \%$ between 1990 and $2004 .{ }^{136}$ With the exception of Oakdale, which has a lower tax capacity more similar to that of the stressed inner suburbs, they all have close to average tax capacity for the metropolitan region. ${ }^{137}$ Like the developed job center group, they are politically diverse and contested; three of the five lean Republican, one leans Democratic, and one is safely Democratic. ${ }^{138}$

The extent of their mitigation efforts varies dramatically. Some of the cities in this grouping that are located closer to the region's core were comparatively early adopters of mitigating activities identified in the cities and climate change literature, even, in the case of Oakdale, with comparatively limited resources. However, one of the outer group, Farmington, has included efforts at land use concentration among its initiatives, a constructive way of addressing sprawl within a city that could be compatible with regional sprawl control efforts. Although in some cases these cities accessed university and governmental resources to support their efforts, they did so less than cities in the other two categories discussed, despite the fact that these cities need such economic support more than the developed job centers. ${ }^{139}$ This gap indicates a possible avenue for encouraging more action in these communities.

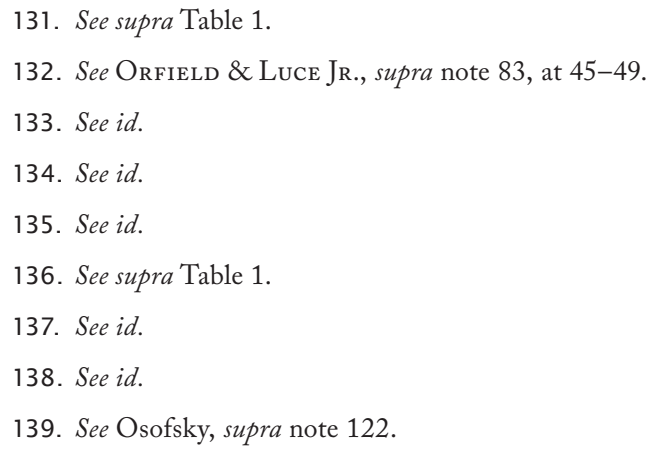




\section{THE GEOGRAPHY OF SOLVING GLOBAL ENVIRONMENTAL PROBLEMS}

The patterns suggested by this preliminary assessment provide an example of the level of nuance needed to effectively engage in "global" problem solving in a polycentric fashion. In particular, with respect to local climate change action, mitigation efforts should be tied to other core needs whenever possible. So, for stressed inner suburbs, measures that help them (1) address poverty, aging infrastructure, and redevelopment needs, and (2) access university and governmental resources may be particularly appropriate and well received. Developed job centers have the capacity to access external resources and provide up-front costs. The challenge there may be having those cities look to models, and recognize climate action as in the local interest, if they are not already doing so. In this group, as in the prior one, the diversity of politics among the sample cities could be helpful; in this time of political divergence, having cities that lean toward the same political party reach out to each other and share their experiences might support more extensive future mitigation efforts. Developing job centers and bedroom communities need more encouragement than the others to build upon their current efforts, use locally available free resources, and expand beyond building and vehicles initiatives to land use and planning measures that can help shape their development in economically beneficial but less carbon intensive ways.

\section{Possibilities for Encouraging Greater Suburban Participation Through Multilevel Networks}

An important part of what helps the Twin Cities suburbs learn, and makes their successes replicable, is their participation in metropolitan, state, regional, national, and transnational networks of cities. As detailed in Table 2 below, many of the studied GreenStep Cities participants have joined other state, regional, national, and international networks, with over half of them members of the Mayors Agreement. The suburbs studied that participated in the Mayors Agreement recorded targets in the Copenhagen City Climate Catalogue of 7\% below 1990 levels of carbon dioxide by 2012 in order to meet their commitment to meet or beat the reduction target that the United States would have had under the Kyoto Protocol. Three of the cities studied-Edina, Mahtomedi, and Oakdale-are also members of ICLEI, a transnational network of cities working on climate change.

Although all of these networks are voluntary, they provide these cities and others with opportunities to create community, see what is possible, and receive both support and pressure. Overall, as explored in more depth in this section and the Appendix, the group studied had higher levels of participation in these multilevel networks than the metropolitan region overall. These patterns suggest a clustering of network participation in cities committed to taking action on sustainability or climate change and the need to explore how these networks are and could be effective vehicles for enhancing participation. This section examines these cities' participation in each of these networks, how the networks interact, and where possibilities for further action through them may lie. 
Table 2: Participation in Multilevel Networks by Twin Cities Metropolitan Region GreenStep Cities

\begin{tabular}{|c|c|c|c|c|c|c|}
\hline & $\begin{array}{l}\text { Date Joined } \\
\text { GreenStep } \\
\text { Cities }^{140}\end{array}$ & 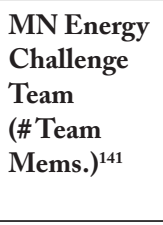 & $\begin{array}{l}\text { EPA Region } 5 \\
\text { Community } \\
\text { Climate } \\
\text { Change } \\
\text { Initiative } \\
\text { Partner }^{142} \\
\end{array}$ & $\begin{array}{l}\text { Mayors } \\
\text { Agreement } \\
\text { on Climate } \\
\text { Change }^{143}\end{array}$ & 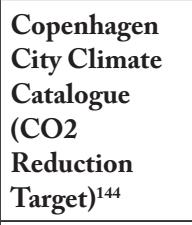 & ICLEI $^{145}$ \\
\hline Apple Valley & $6 / 2011$ & 466 & $\begin{array}{l}\text { As of July } \\
2009\end{array}$ & $\begin{array}{l}\text { Mary Hamann- } \\
\text { Roland }\end{array}$ & $\begin{array}{l}7 \% \text { by } 2012 \\
\text { (1990 baseline) }\end{array}$ & \\
\hline Cottage Grove & $11 / 2011$ & 119 & & & & \\
\hline Eagan & $8 / 2010$ & 387 & & Mike Maguire & $\begin{array}{l}7 \% \text { by } 2012 \\
\text { (1990 baseline) }\end{array}$ & \\
\hline Eden Prairie & $6 / 2011$ & 225 & & $\begin{array}{l}\text { Nancy Tyra- } \\
\text { Lukens }\end{array}$ & $\begin{array}{l}7 \% \text { by } 2012 \\
\text { (1990 baseline) }\end{array}$ & 2007 \\
\hline Edina & $1 / 2011$ & 503 & & James Hovland & $\begin{array}{l}7 \% \text { by } 2012 \\
(1990 \text { baseline }) \\
\end{array}$ & \\
\hline $\begin{array}{l}\text { Falcon } \\
\text { Heights }\end{array}$ & $1 / 2011$ & 79 & $\begin{array}{l}\text { As of July } \\
2009\end{array}$ & Peter Lindstrom & $\begin{array}{l}\% \text { by } 2012 \\
(1990 \text { baseline) } \\
\end{array}$ & \\
\hline Farmington & $4 / 2011$ & 189 & & & & \\
\hline Hopkins & $10 / 2010$ & 118 & & & & \\
\hline Mahtomedi & $10 / 2010$ & 58 & & Judson Marshall & \begin{tabular}{|l}
$7 \%$ by 2012 \\
$(1990$ baseline $)$ \\
\end{tabular} & 2008 \\
\hline Maplewood & $12 / 2010$ & 135 & $\begin{array}{l}\text { Prior to July } \\
2009\end{array}$ & Diana Longrie & $\begin{array}{l}7 \% \text { by } 2012 \\
(1990 \text { baseline) }\end{array}$ & \\
\hline Oakdale & $3 / 2011$ & 189 & $\begin{array}{l}\text { As of July } \\
2009\end{array}$ & & & 2008 \\
\hline St. Anthony & $2 / 2011$ & 28 & & & & \\
\hline
\end{tabular}

140. See GreenStep Cities List, supra note 112.

141. See Team Standings: City Teams, Minn. Energy Challenge, http://www.mnenergychallenge.org/ Teams/City-Teams.aspx (last visited Mar. 29, 2014) [hereinafter City Teams].

142. See Region 5 Climate Change: Municipalities, U.S. Envtl. Prot. Agency, http://epa.gov/r5climatechange/ municipalities.html\#3 (last visited Mar. 29, 2014) [hereinafter Region 5 Municipalities].

143. See List of Participating Mayors, supra note 35.

144. The Copenhagen City Climate Catalogue and related information were no longer available online as this essay was being prepared for publication. However, my previous articles contain this data, which was obtained when this information was still available online. See Osofsky, supra note 122, at 442-48; Osofsky, supra note 27, at 66.

145. The list of ICLEI member cities in the United States was no longer available via that organization's website by the time this essay was being prepared for publication. As of March 2014, certain local civic groups were publishing cached verions of the ICLEI's U.S. membership list on their websites. See, e.g., Member List-ICLEI Local Governments for Sustainability USA, DownTownCARY, http://downtowncary. org/member-list-iclei-local-governments-for-sustainability-usa/ (last visited Mar. 29, 2014) [hereinafter ICLEI Member List]. 


\section{THE GEOGRAPHY OF SOLVING GLOBAL ENVIRONMENTAL PROBLEMS}

As Table 2 reflects, cities in all three categories of suburbs studied are active in statewide networks. In addition to participating in GreenStep Cities, all twelve cities in the sample have teams in the Minnesota Energy Challenge, in which cities (and other organizations) form teams of people that track energy savings; for cities, the teams are comprised of residents. ${ }^{146}$ Although the cities have significant variation in the number of residents participating, in every case it is a low percentage of the overall population in that city. ${ }^{147}$ These patterns of participation are higher than those of the overall region, but the region as a whole also has a pattern of greater participation in the statewide Minnesota Energy Challenge than other types of networks; the majority of the Met Council's 183 communities have teams with at least ten members. ${ }^{148}$

In contrast, GreenStep Cities, even with significant growth in membership over the last two years, still lags the Minnesota Energy Challenge in suburban participation. Beyond the twelve cities studied in this essay, only five other cities from the metropolitan region-all suburbs - were members of GreenStep Cities as of the January 2012 initial study. ${ }^{149}$ GreenStep Cities has added many members since then; as of April 2014, it had sixty-four member cities, thirty of which are in the Twin Cities metropolitan region. However, as the Appendix details, there still are a number of cities that are very active in other networks but have not joined GreenStep Cities. Confidential interviews with people from some of those cities suggest that, in certain cases, they may not be joining GreenStep Cities out of the sense that the program is too basic for them. ${ }^{150}$

Participation levels of these suburbs decline for the larger-scale networks that focus more explicitly on climate change. Only four of the twelve cities studied are involved in the EPA Region 5 Community Climate Change Initiative partnership programs. ${ }^{151}$ The EPA provides six free programs for cities involved in this initiative: EnergyStar, ${ }^{152}$ WasteWise, ${ }^{153}$ Combined Heat and Power Partnership, ${ }^{154}$ Green Power

146. About the Challenge, Minn. Energy Challenge, http://www.mnenergychallenge.org/About-theChallenge.aspx (last visited Mar. 29, 2014) [hereinafter About MN Energy Challenge].

147. See supra Table 1; see also supra Table 2.

148. See infra Appendix; see also City Teams, supra note 141.

149. See GreenStep Cities List, supra note 112 (listing cities participating in this initative).

150. See id.; confidential interviews referenced supra note 120 .

151. See Region 5 Municipalities, supra note 142.

152. See About ENERGY STAR, ENERGY STAR, http://www.energystar.gov/about (last visited Mar. 29, 2014).

153. See Conserving Resources, Preventing Waste, U.S. Envtl. Рвот. Agency, http://www.epa.gov/osw/// conserve/smm/wastewise/index.htm (last visited Mar. 29, 2014).

154. See Combind Heat and Power Partnership, U.S. Envtl. Prot. Agency, http://www.epa.gov/chp/index. html (last visited Mar. 29, 2014). 
Partnership, ${ }^{155}$ WaterSense, ${ }^{156}$ and Landfill Methane Outreach Program. ${ }^{157}$ The EPA website explains that "partnership programs help communities address climate change while protecting human health and the environment, enhancing local economies, and reducing energy costs. These programs also help meet commitments in the Mayors Agreement and other climate change programs." 158 The low participation levels across all three groups of cities suggest that even though the EPA explicitly connects these programs with accomplishing the goals of the Mayors Agreement, which many more of the cities have joined, these cities either find this program less valuable or are unaware of it. This pattern persists across the metropolitan region, with only two cities beyond the group studied participating in this program..$^{159}$

The biggest differentiation among the categories of suburbs studied comes with the national-level network, the Mayors Agreement. This agreement, and its accompanying U.S. Conference of Mayors Climate Protection Center, emerged from a 2005 initiative by Seattle Mayor Greg Nickels, which was unanimously supported by the U.S. Conference of Mayors. ${ }^{160}$ Participating cities not only commit to what the United States' Kyoto Protocol emissions reductions would have been, but also have the opportunity to learn from the best practices models and receive national recognition (as Eden Prairie has). ${ }^{161}$ While more than half of the studied suburbs (seven of the twelve) are members of this agreement - a much higher level of participation than in the metropolitan region as a whole, which only has twenty-one total participants including the studied suburbsthis participation is not distributed evenly. All of the developed job centers studied are members of this agreement. However, a much lower percentage of the other two groups are-one out of three stressed cities and two out of five developing job centers and bedroom developing communities. ${ }^{162}$

This pattern of greater developed job center participation does not carry over, however, to the other fourteen metropolitan-area cities that have joined the Mayors Agreement; two are center cities (Minneapolis and Saint Paul), four are stressed

155. See Green Power Partnership, U.S. Envtr. Рrot. Agency, http://www.epa.gov/greenpower/ (last visited Mar. 29, 2014).

156. See WaterSense, U.S. Envtl. Рrot. Agency, http://www.epa.gov/watersense/ (last visited Mar. 29, 2014).

157. See Landfill Methane Outreach Program, U.S. Envtr. Рrot. Agency, http://www.epa.gov/lmop/ (last visited Mar. 29, 2014).

158. Region 5 Municipalities, supra note 142.

159. See id.

160. See About the Mayors Climate Protection Center, supra note 35.

161. Eden Prairie Mayor Nancy Tyra-Lukens was awarded an honorable mention at the 2011 U.S. Mayors Climate Protection Awards in the "small city" category for the city's work on its "20-40-15" initiative. See Press Release, Eden Prairie Minn., Mayor Receives Honorable Mention for Eden Prairie Climate Protection Efforts (June 17, 2011), available at http://www.edenprairie.org/modules/showdocument. aspx?documentid=1022; see also 20-40-15 Initiative, Eden PraIrIE, MN, http://www.edenprairie.org/ index.aspx?.page=334 (last visited Apr. 23, 2014). In addition, Eden Prairie has received recognition for its water conservation efforts. See Press Release, Eden Prairie Minn., Eden Prairie Wins Water Conservation Challenge (May 3, 2012), available at http://edenprairie.org/index.aspx?page=380\&recordid=65.

162. See supra Table 2. 


\section{THE GEOGRAPHY OF SOLVING GLOBAL ENVIRONMENTAL PROBLEMS}

cities (Brooklyn Center, Burnsville, Crystal, and White Bear Lake), four are developed job centers (Golden Valley, Minnetonka, Oak Park Heights, and Roseville), one is an affluent residential community (Sunfish Lake), and three are developing job centers (Inver Grove Heights, Rosemount, and Woodbury). ${ }^{163}$ When the metropolitan region is viewed as a whole, combining the studied cities with the other cities, there are more developed job centers participating as compared to any other group, but the difference is less marked than in the group discussed in depth in this essay. ${ }^{164}$ On a percentage basis, though, the differences still look significant because there are far fewer developed job centers than developing job centers in the metropolitan region; a much higher percentage of developed job centers are participating than any other type of Twin Cities suburb. ${ }^{165}$

The greater participation of developed job centers in the Mayors Agreement among the studied group and, to some extent, among metropolitan region suburbs as a whole, indicates that outreach to cities in the other two groupings potentially would be valuable for determining if there are barriers to joining, such as political concerns about framing efforts as climate change mitigation, or if these cities could be encouraged to take this additional step. The developed job center participation might serve as a model for those cities with political concerns, as they are equally divided between leaning Democratic or Republican. ${ }^{166}$

Numerous international networks exist among local governments on climate change, including ICLEI; ${ }^{167}$ agreements made in conjunction with the annual UNFCCC COP, such as pledges entered in the Copenhagen City Climate Catalogue, ${ }^{168}$ the Mexico City Pact, ${ }^{169}$ and the Durban Adaptation Charter for Local Government; ${ }^{170}$ the World Mayors Council on Climate Change; ${ }^{171}$ and the carbon $n$

Cities Climate Registry. ${ }^{172}$ However, the suburbs in this sample and the metropolitan region as a whole have only significantly participated in ICLEI and the Copenhagen City Climate Catalogue. The main exception is Burnsville, whose mayor was

163. See List of Participating Mayors, supra note 35; Orfield \& Luce JR., supra note 83, at 44 map 1.17.

164. See Orfield \& Luce Jr., supra note 83, at 44 map 1.17.

165. See id.; List of Participating Mayors, supra note 35.

166. See supra Table 1.

167. See Who We Are, ICLEI, http://www.iclei.org/iclei-global/who-is-iclei.html (last visited Mar. 29, 2014) [hereinafter About ICLEI].

168. See supra note 144 and accompanying text.

169. See Signatories, Тне Mexico Сiту Раст, http://www.mexicocitypact.org/en/the-mexico-city-pact-2/ list-of-cities/ (last visited Mar. 29, 2014) [hereinafter Mexico City Pact Signatories].

170. See Durban Adaptation Charter, ICLEI, http://www.durbanadaptationcharter.org/ (last visited Mar. 29, 2014).

171. Membership, World Mayors Council on Climate Change, http://www.worldmayorscouncil.org/ members/members-list.html (last visited Mar. 29, 2014).

172. City Search, carbonn Cities Climate Registry, http://citiesclimateregistry.org/data/ (last visited Mar. 29, 2014). 
president of the U.S. Conference of Mayors at the time of the Mexico City Pact, and signed on behalf of both Burnsville and the U.S. Conference of Mayors. ${ }^{173}$

ICLEI, like GreenStep Cities, focuses on sustainability. Since its founding in 1990, the association has grown to include participation from 1,220 local government members from seventy different countries representing 569,885,000 people. ${ }^{174}$ ICLEI has several different programs to achieve its sustainability goals, one of which is addressing climate change. Its climate program has played a leading role in developing the agreements made during the COPs by fostering networks among local governments and supporting individual governments in their climate change efforts. ${ }^{175}$ Fifteen Minnesota cities are members of ICLEI, including Minneapolis, Saint Paul, and several Twin Cities suburbs. Only one suburb from each of the three groupings studied has joined. ${ }^{176}$ In the metropolitan region as a whole, five more cities are members: the two center cities, two developed job centers (Roseville and Golden Valley), and one developing job center (Woodbury). ${ }^{177}$ Thus, overall, developed job centers are slightly overrepresented, but the sample size is very small.

The Copenhagen City Climate Catalogue was created in conjunction with the 2009 COP. Participating cities record their targets and actions to share information with one another and to demonstrate the importance of local governments to the negotiating nation-states. Unlike the Mexico City Pact and Durban Adaptation Charter, which require signatories to make particular commitments, the Catalogue just serves as a clearinghouse for local governments to record their voluntary activities. As Table 2 illustrates, the studied suburbs that participated in the Catalogue are Mayors Agreement signatories; their only commitments under the Catalogue are those that they are already making under the Mayors Agreement. ${ }^{178}$ The other Twin Cities suburbs participating in the Mayors Agreement, with the exception of Crystal, follow an identical pattern. ${ }^{179}$ The Catalogue helps translate these suburbs' national-level commitments into international-level commitments, but those suburbs have not made additional international-level commitments at the COPs that followed. ${ }^{180}$ Interestingly, while participation in the Mayors Agreement correlates perfectly with those making Catalogue commitments, it varies substantially from those participating in either the regional-level EPA partnership or the international-level ICLEI network, both among

173. See List of Cities That Have Signed the Global Cities Covenant on Climate (The Mexico City Pact), WorLD Mayors Summit on Climate-Mex. City, http://www.wmsc2010.org/list-of-cities/ (last visited Mar. 29, 2014).

174. See About ICLEI, supra note 167.

175. See, e.g., Introduction to Climate and Energy Action, ICLEI, http://www.icleiusa.org/climate_and_energy/ introduction-to-climate-and-energy (last visited Mar. 29, 2014).

176. See supra Table 2 and accompanying notes 140-86.

177. See ICLEI Member List, supra note 145; supra Table 2.

178. See supra Table 2 and accompanying notes 140-45; supra note 163 and accompanying text.

179. See generally id.

180. See Mexico City Pact Signatories, supra note 169; Durban Adaptation Charter, supra note 170. 


\section{THE GEOGRAPHY OF SOLVING GLOBAL ENVIRONMENTAL PROBLEMS}

the studied group and the broader metropolitan region. ${ }^{181}$ This difference suggests that suburbs willing to make commitments on climate change (as opposed to just sustainability) are participating unevenly in the possible networks that might support them, and that an opportunity might exist to introduce suburbs actively working on climate change to additional networks.

Overall, these patterns of network participation indicate that state-level networks focused on sustainability and energy savings may serve as an important starting point for suburban mitigation, and that climate change networks may not be politically unpalatable to moderately conservative suburbs. However, participation in one network does not necessarily translate into participation in other networks, and networks vary in the extent to which they result in new action rather than just a rereporting of current action. Suburbs already interested in taking action are more likely to join these networks, ${ }^{182}$ making it sometimes difficult to discern the extent to which network participation resulted in new or more effective activities.

Most promisingly, networks with specific action steps seem to motivate particular action. For example, Falcon Heights joined numerous networks in a short period of time when it committed to sustainability and climate change goals. ${ }^{183}$ Although the networks did not cause it to commit to these goals, the frameworks provided by the networks, such as the steps of GreenStep Cities, helped organize its efforts and encouraged it to take particular actions. ${ }^{184}$ Other cities have reported similar experiences. ${ }^{185}$ This anecdotal evidence based on this small sample of cities suggests the need for further empirical research-which I am in the process of conductinginto how to motivate different types of suburbs to join additional networks, and what makes networks most effective in spurring new or more effective mitigation steps in order to maximize cumulative suburban action. ${ }^{186}$ Future studies might also consider how the motivations of different types of suburbs and center cities compare as they join networks, and how these varying motivations should impact the strategies of these networks.

181. See generally List of Participating Mayors, supra note 35; Region 5 Municipalities, supra note 142; ICLEI Member List, supra note 145.

182. See Confidential Presentation to Hari Osofsky's Climate Change and Clean Energy Capstone (Fall 2011) (notes on file with author).

183. See supra Part III.B.

184. See Beth Mercer-Taylor, Member, Falcon Heights City Council, Presentation to Renewable Energy Class at the University of Minnesota (Feb. 7, 2012).

185. See Confidential Presentation, supra note 182.

186. I am currently engaged in this broader research through the support of the 2013-14 Fesler-Lampert Chair in Urban and Regional Affairs. There are also a number of efforts by researchers to assess the GreenStep Cities program and what it has achieved, but those generally are not focused primarily on climate change mitigation but rather on the program's sustainability goals. 


\section{Possibilities for Integrating Multilevel Networks with Formal Governance}

Viewing suburban action as part of a polycentric, pluralist approach to addressing climate change does not necessarily have significant implications for formal international legal efforts to address climate change through international treaties. The suburbs could simply serve as an important source of mitigation in the aggregate and through participation in networks that function wholly separately from the COP negotiations. However, in reality, cities (including suburban ones) and the networks that they form interact with the treaty negotiations in a variety of ways. This section examines these interactions and considers how a governance model for climate change might incorporate them.

The primary ways for smaller-scale governments to have a direct voice in UNFCCC negotiations are: (1) through their nation-state, by serving on their national negotiating team and influencing its positions, and (2) as one of many civil society groups that observe the meetings (when not shut out as they were in Copenhagen in 2009) and provide input into negotiating texts. Local representatives, particularly from major center cities, are at times directly involved in national negotiating teams, ${ }^{187}$ but these teams are size-limited and could never include all U.S. mayors. Small suburban cities could never be fully included on them except through designated representatives, and would have to compete with larger cities for a place in that group.

However, cities have effectively had a voice in negotiations through this second avenue paired with efforts by multilevel networks - in which many of these suburbs participate - to influence national positions and international agreements through the commitments that local governments publicly make among themselves. Transnational networks of localities have been working to change the substance of the agreements among nation-states at the COPs to have them include more recognition of the local role. ${ }^{188}$ Since the 2007 COP in Bali established a climate roadmap for nation-states, localities under the leadership of ICLEI and United Cities and Local Governments $(\mathrm{UCLG})^{189}$ have attempted to advance a Local Government Climate Roadmap. ${ }^{190}$ This effort, which was originally designed to conclude by the Copenhagen COP, continued through the 2011 COP in Durban and beyond. It aims to have references

187. See Osofsky, supra note 2, at 648 n.247 (citing Gavin Newsom, Mayor of S.F., Remarks Following Keynote Address at the University of California, Hastings College of the Law Conference: Surviving Climate Change: Adaptation and Innovation (Apr. 4, 2008)).

188. See Press Release, ICLEI, Durban Outcomes: Nations Invest in Time, World Must Invest in Cities (Dec. 12, 2011), available at http://www.iclei-europe.org/fileadmin/templates/iclei-europe/files/ content/ICLEI_IS/Press_releases/2011/12.12.11_COP17_Outcomes.pdf.

189. See About Us, UCLG, http://www.uclg.org/ (last visited Mar. 29, 2014).

190. See Local Government Climate Roadmap, ICLEI, http://www.iclei.org/index.php?id=1197 (last visited Mar. 29, 2014). 


\section{THE GEOGRAPHY OF SOLVING GLOBAL ENVIRONMENTAL PROBLEMS}

to local governments and subnational governments more broadly included in the texts of the agreements concluded under the UNFCCC. ${ }^{191}$

The agreements made at the 2011 COP in Durban reflect how far these efforts have come. As ICLEI highlighted in its preliminary assessment, key agreements referenced local governments directly or made room for their participation as stakeholders. The Durban outcome of the Ad Hoc Working Group on Long-Term Cooperative Action Under the Convention, ${ }^{192}$ for example, maintained the recognition of local governments that came out of the 2010 COP in Cancún, Mexico and added several new references to them in the context of nationally appropriate mitigation actions, adaptation, and technology development and transfer. ${ }^{193}$ The Durban Platform did not explicitly reference local governments, but included a mechanism for observer organizations to provide input on both options and increase the level of ambition. ${ }^{194}$ The Green Climate Fund ${ }^{195}$ launch similarly made reference to stakeholders and active observers at various points, and the Fund specifically includes subnational entities as among those that can be accredited as implementing entities receiving funding. ${ }^{196}$ The Technology Executive Committee's ${ }^{197}$ modalities and procedures include the subnational level explicitly in their reference to engaging stakeholders. ${ }^{198}$ Agreements regarding national adaptation plans and loss and damage all specifically reference multiple levels, at times using terms such as "subnational" and "local." 199 Finally, the Clean Development Mechanism Executive Board ${ }^{200}$ made decisions that continued efforts from the 2010 Cancún COP to make it easier for

191. See From Copenhagen to Cancuin to South Africa: COP15 - COP16 - COP17, Local Gov't Climate Roadmap (ICLEI, Bonn, Ger.), July 2010, available at http://archive.iclei.org/fileadmin/user_upload/ documents/Africa/Programs/Energy_and_Climate_Change/Roadmap/Concept_towards_COP16_ Final_29July2010_01.pdf.

192. See UNFCCC Decision 2/CP.17, Outcome of the Work of the Ad Hoc Working Group on Long-Term Cooperative Action Under the Convention, 17th Sess., Nov. 28-Dec. 11, 2011, CP/2011/9/Add.1, at 4-55 (Dec. 11, 2011) [hereinafter Durban Outcome], available at http://unfccc.int/resource/docs/2011/ cop17/eng/09a01.pdf.

193. See generally id.

194. See id.

195. See Mandate and Governance, Green Climate Fund, http://gcfund.net/home.html (last visited Mar. 29, 2014).

196. See id.

197. See Technology Executive Committee, UNFCCC, http://unfccc.int/ttclear/pages/tec_home.html (last visited Mar. 29, 2014).

198. See id.

199. See, e.g., UNFCCC Decision 1/CP.16, The Cancún Agreements: Outcome of the Work of the Ad Hoc Working Group on Long-Term Cooperative Action Under the Convention, 16th Sess., Nov. 29-Dec. 10, 2010, CP/2010/7/Add.1, at 3, 5 (Dec. 11, 2010), available at http://unfccc.int/resource/docs/2010/ cop16/eng/07a01.pdf\#page=19.

200. See What Is the CDM Executive Board?, UNFCC, https://cdm.unfccc.int/EB/index.html (last visited Mar. 29, 2014). 
citywide programs to participate. ${ }^{201}$ While ICLEI indicates a number of places in the agreements where clarification that stakeholders include localities would be helpful, the nation-state agreements increasingly recognize the plurality of relevant actors in addressing climate change within the limited participatory framework that international law treaties provide. ${ }^{202}$

While ICLEI and UCLG use their status as observers to influence the text, these efforts are augmented by the side meetings among localities (and other subnational governments) at the COPs. As described above, these meetings have resulted in parallel agreements among localities at each of the last several COPs that were intended both to promote local action on mitigation and adaptation and to pressure nation-states to take more aggressive steps. The Twin Cities suburbs participating in the Mayors Agreement and Copenhagen City Climate Catalogue exemplify this type of effort by the ways in which they publicly exceed U.S. commitments and use the Kyoto Protocol as a frame of reference in doing so. ${ }^{203}$ At the Copenhagen COP, the Twin Cities suburbs making commitments were part of a much larger effort; mayors representing more than half of the world's population registered 3,222 reduction targets. ${ }^{204}$ While the Twin Cities suburbs reduction targets pale in comparison to a leader center city like Portland, Oregon-10\% by 2010 , $80 \%$ by 2050 - they are equivalent to those of one of its local center cities, Saint Paul. ${ }^{205}$

201. See UNFCCC Decision 3/CMP.1, Modalities and Procedures for a Clean Development Mechanism as Defined in Article 12 of the Kyoto Protocol, 1st Sess., Nov. 28-Dec. 10, 2005, KP/CMP/2005/8/Add.1, Annex (Dec. 10, 2005), available at http://unfccc.int/resource/docs/2005/cmp1/eng/08a01.pdf\#page=07.

202. See LGs@COP 17: Urbanize Climate Agenda, ICLEI eNews (Dec. 5, 2011), http://hosted. verticalresponse.com/413987/3ecbf9500d/TEST/TEST/.

203. See generally List of Participating Mayors, supra note 35; Region 5 Municipalities, supra note 142; ICLEI Member List, supra note 145.

204. See Cities Act: The Copenhagen Climate Communiqué (Dec. 2009), available at http://www.nyc. gov/html/planyc2030/downloads/pdf/cities_act_copenhagen_communique.pdf; Michael de Laine, \#COP15 Mayors Sign Communique To Show They Mean Business in Mitigating Climate Change, The Copenhagen Voice (Dec. 21, 2009, 5:11 PM), http://cphvoice.ning.com/profiles/blogs/cop15-mayorssign-communique.

205. Minneapolis's commitments are harder to translate into 1990 equivalents; although it uses a 2006 baseline, its substantial efforts prior to 2006 and efforts to address accuracy issues in its baseline make that a very different choice than the United States' use of a 2005 baseline. See generally Climate Change Corps of the Minn. Retired Engineers Technical Assistance Program, Minneapolis Carbon Footprint Project Report (2008), available at http://s3.amazonaws.com/zanran_storage/www.ci.minneapolis. mn.us/ContentPages/4058400.pdf; City of Minneapolis, Sustainability Initiative: 2005 Annual REPORT ii (2005), available at http://www.minneapolismn.gov/www/groups/public/@citycoordinator/ documents/webcontent/convert_270332.pdf; John Bailey, Lessons from the Pioneers: Tackling Global Warming at the Local Level 7 n.5 (2007), available at http://community-wealth.org/content/ lessons-pioneers-tackling-global-warming-local-level ("Minneapolis did develop a baseline GHG inventory in 1993 for the year 1988, but a recent examination led the city to reconsider its accuracy. A new baseline analysis and current inventory are in the process of being developed."). Minneapolis was recognized nationally in 2007 for its cross-cutting efforts on climate change and sustainability. See Mayors Climate Prot. Ctr., Climate Protection Strategies and Best Practices Guide 15-16 (2007), available at http://www.usmayors.org/climateprotection/documents/2007bestpractices-mcps.pdf. 


\section{THE GEOGRAPHY OF SOLVING GLOBAL ENVIRONMENTAL PROBLEMS}

Moreover, when viewed in the context of the limited nation-state commitments made during the formal negotiations at Copenhagen and at the COPs since then, these suburban targets in the Copenhagen City Climate Catalogue appear much more impressive. The nation-states lacked consensus to pass an agreement at Copenhagen but took note of the Copenhagen Accord. ${ }^{206}$ Under that Accord, the United States set a 2020 emissions reductions target "[i]n the range of 17\%, in conformity with anticipated U.S. energy and climate legislation," using the less ambitious base year of 2005 (rather than the suburbs' 1990 base year); translated into a 1990 base year, that would be less than a $4 \%$ reduction. ${ }^{207}$ In addition, the United States still has not passed such legislation and none looks likely in the near term. ${ }^{208}$ Although the 2011 Durban COP resulted in an agreement to reach a universal binding agreement by 2015 paired with the creation of an ad hoc working group on the Durban Platform to develop a new protocol or other legal approach, only the Kyoto Protocol parties currently have specific, binding commitments to mitigate climate change. ${ }^{209}$ While some of the Kyoto Protocol parties agreed to a second commitment period at the Durban COP, the United States continues to refrain from becoming a party and making such commitments. ${ }^{210}$

This contrast between small suburban commitments and U.S. commitments suggests both the contributions and limitations of these treaty interventions and example-setting transnational local agreements in advancing climate change action. Leader cities, even ones not as far along as the Twin Cities suburbs highlighted in this essay, help their nation-states meet emissions reductions goals and pressure them to cooperate internationally while supporting each other's local goals. Perhaps in part because they are not making legally binding commitments to one another, ${ }^{211}$ these cities make agreements with and commitments to other cities at international, national, regional, and state scales. The increasing recognition of localities and

206. See UNFCCC Decision 2/CP.15, Copenhagen Accord, 15th Sess., Dec. 7-19, 2009, CP/2009/11/ Add.1, at 4-10 (Dec. 19, 2009), available at http://unfccc.int/resource/docs/2009/cop15/eng/11a01.pdf; see also Arthur Max, Obama Brokers a Climate Deal, Doesn't Satisfy All, Associated Press Int'u (Dec. 19, 2009), http://www.timesfreepress.com/news/2009/dec/19/obama-brokers-climate-deal-doesntsatisfy-all/?print; Andrew C. Revkin \& John M. Broder, A Grudging Accord in Climate Talks, N.Y. Times (Dec. 19, 2009), http://www.nytimes.com/2009/12/20/science/earth/20accord.html.

207. See Appendix I-Quantified Economy-Wide Emissions Targets for 2020, UNFCCC, http://unfccc.int/ meetings/cop_15/copenhagen_accord/items/5264.php (last visited Mar. 29, 2014). The U.S. commitment would constitute only about a $3.45 \%$ reduction if a 1990 baseline were used. U.S. Envtl. Prot. Agency, Executive Summary: Inventory of U.S. Greenhouse Gas Emissions and Sinks: 1990-2005, at 5 (2007), available at http://www.epa.gov/climatechange/Downloads/ghgemissions/07ES.pdf.

208. The American Clean Energy and Security Act of 2009 passed in the House but the Senate failed to pass equivalent legislation; no such legislation is currently pending. See H.R. Res. 2454, 111th Cong. (2009), 2010 Bill Tracking H.R. 2454 (LEXIS).

209. See Durban Platform AWG Decision, supra note 13.

210. See Durban Outcome, supra note 192.

211. For a discussion of nation-states as the primary subjects and objects of international law, see BrownLIE, supra note 21 , at $287-88$. 
subnational governments in treaties reinforces localities' growing role in both formal and informal visions of multilevel climate change governance.

However, these activities by a range of leader cities that include suburbs also serve to reinforce a troubling big picture. Other cities within the Twin Cities region and beyond lag well behind the suburbs highlighted in this essay (which vary in their level of action). ${ }^{212}$ The collaboration among localities has not eliminated the many barriers to nation-state agreement or to localities being given a fuller place at the negotiating table. ${ }^{213}$ Thus, while these suburbs' efforts play an important role in responding to climate change and in encouraging other key actors to do the same, local climate change efforts remain constrained by the small percentage of cities participating and cities' limited status under international law. This mix of achievements and barriers provides the basis for the proposals advanced in the next section.

\section{E. Proposals for Increasing the Impact of Multilevel Networks}

This section proposes two ways in which, based on this case study of these Twin Cities suburbs, multilevel networks could work more effectively with suburbs to achieve mitigation and adaptation goals. First, it recommends that networks create more differentiated strategies and outreach that take into account the ways in which types of suburbs vary. Second, it suggests that networks should encourage more cross-network participation in order to achieve their policy and governance goals.

\section{Differentiating Strategies Based on Type of Suburb}

As described in more depth in Part IV.C, the networks studied provide cities with a toolkit of options for local or larger-scale activities. ${ }^{214}$ While these toolkits vary based on the network's substantive focus (sustainability versus climate change) and its goals, they generally do not differentiate greatly among cities. For example, GreenStep Cities lists a set of possible actions, each associated with points, and cities can choose how to accumulate points to reach a step. ${ }^{215}$ The Minnesota Energy Challenge gives individuals participating on teams, only some of which are locally based (schools and neighborhoods can also provide teams), a myriad of options for making energy savings that can count toward their team's total. ${ }^{216}$ EPA Region 5 Community Climate Change Initiative partnership programs similarly give cities a

212. For concerns about leakage due to unequal local commitments, see Jonathan B. Wiener, Think Globally, Act Globally: The Limits of Local Climate Policies, 155 U. PA. L. Rev. 1961, 1962 (2007).

213. For a summary of the state of international negotiations under the UNFCCC agreement after the 2010 Cancún meeting, see Cesare Romano \& Elizabeth Burleson, The Cancún Climate Conference, Aм. Soc'Y InT'L L. Insights (Jan. 21, 2011), http://www.asil.org/insights/volume/15/issue/2/canc\%C3\%BAnclimate-conference.

214. See supra Part IV.C.

215. See GreenStep Cities, supra note 98.

216. See About MN Energy Challenge, supra note 146. 


\section{THE GEOGRAPHY OF SOLVING GLOBAL ENVIRONMENTAL PROBLEMS}

choice of six programs in which they can participate. ${ }^{217}$ The Mayors Agreement, beyond its requirement of member commitment to specific greenhouse gas reduction goals, provides recognition of best practices differentiated by city size (large versus small) to give models to its members. ${ }^{218}$ ICLEI's climate program includes steps that cities can take on mitigation, adaptation, and advocacy, with expectations that member cities are engaging in particular practices. ${ }^{219}$ The Copenhagen City Climate Catalogue contains many options for participating cities to take and recognizes them with green check marks on its website when they do. ${ }^{220}$

This toolkit approach has value because almost all cities have common characteristics that shape the categories of actions that would be appropriate. By providing cities with many options in each category, models for how to make progress, and expectations that participation translates into particular steps, these networks can help a very diverse set of cities create individualized plans. The suburbs studied in this essay reflect the appropriateness of this approach as they take steps in the major areas in which cities have authority and record their progress in these various networks. ${ }^{21}$

However, as this essay's examination of these cities based on the type of suburb indicates, small suburban cities appear to vary in their needs and possibilities for action based on the type of suburb that they are. While a broader empirical study is needed to provide a clearer sense of these patterns, ${ }^{222}$ this initial qualitative examination suggests the value in differentiating further among suburbs and providing them with support and models based on their characteristics. For example, networks could emphasize the interconnection between urban redevelopment and greenhouse gas emissions reduction for stressed inner suburbs, while focusing on city layout choices for the more rapidly growing outer suburbs. They also could target suburbs that have not connected to particular types of free resources from governments and universities, which appear in this sample to vary significantly by category, and help them make those connections. ${ }^{223}$

This kind of differentiation would not require massive amounts of additional work for the existing networks, all of which have well-developed websites. It simply would require adding to networks' websites and brochures more differentiated models of how different types of suburbs have taken steps and locally specific examples of resources available and the ways in which other cities have used them. In the Twin Cities context, with its rich opportunities for interconnection among the metropolitan

217. See Region 5 Municipalities, supra note 142.

218. See MCPC Best Practices, supra note 130.

219. See Sustainable City, ICLEI, http://www.iclei.org/our-activities/our-agendas/sustainable-city.html (last visited Mar. 29, 2014).

220. See supra note 144 and accompanying text.

221. See supra Part IV; supra Table 2.

222. I am in the process of conducting this broader study to build upon this essay.

223. See supra Part IV.B. 
cities due to its regional governance structure and statewide programs, adding this dimension to existing efforts would be relatively straightforward and within the powers of current networks. For example, GreenStep Cities could complement its existing web resources for participants, which currently include best practices and model ordinances, ${ }^{224}$ with case examples from its different types of participating suburbs, and lists of locally available financial and technical (including university) assistance.

\section{Greater Interconnection Among Voluntary Networks}

The networks studied in this Part vary significantly in their substantive focus and scale of operations. Some of them, like GreenStep Cities, are not even explicitly engaging climate change, but rather positively impact mitigation through their broader sustainability goals; they may be able to foster action in communities where the problem of climate change is more controversial. Despite these differences, though, these networks are often trying to encourage cities to take very similar steps. At times, the networks on climate change even explicitly interlink their activities, such as when the Mayors Agreement cities make uniform Copenhagen City Climate Catalogue commitments or when the EPA Region 5 Community Climate Change Initiative partnership programs indicate that they will help cities meet their Mayors Agreement obligations. ${ }^{225}$

These twelve cities' pattern of involvement in these networks and that of cities in the metropolitan region as a whole, however, suggests missed opportunities for greater synergy. While, as in the case of the first proposal, additional empirical work would be valuable, the disconnections among the networks in this sample and the region seem to go well beyond the political volatility of climate change. For example, many of the cities that have joined the Mayors Agreement are not participating in either the EPA Region 5 initiative or ICLEI, despite their complementary resources and commitments. ${ }^{226}$ This gap suggests an opportunity for networks to work together to encourage cities willing to take action on climate change to take full advantage of the resources available to them and become involved in new multilevel initiatives. Like with the first suggestion, this recommendation would be relatively simple to implement: each network could advertise the other available networks to their members with explanations of the synergistic possibilities of participation in additional networks.

Creating more common participation among these networks could also advance their more effective inclusion in international and national climate change governance, in line with pluralist and polycentric models. At the international level, as ICLEI in partnership with UCLG simultaneously works to have localities and subnational governments included in treaties and make parallel commitments, it

224. See GreenStep Cities, supra note 98.

225. See supra Part IV.C.

226. See id. 


\section{THE GEOGRAPHY OF SOLVING GLOBAL ENVIRONMENTAL PROBLEMS}

would be aided by having more small suburban members, given their critical role in addressing urban emissions. Encouragement of cross-participation by other networks could help to achieve this greater representation and more engagement of the particular issues faced by different types of suburbs. Such an approach also would comport well with the calls for greater participation by localities in UNFCCC negotiations and implementation in line with conventions like the Aarhus Convention, ${ }^{227}$ which some UNFCCC parties have joined. ${ }^{228}$

At the U.S. national level, various models have been proposed for involving localities more in the formulation of the U.S. negotiating position and federal climate change law and policy. For example, Professor Judith Resnik, Joshua Civin, and Joseph Frueh have suggested mechanisms for integrating these subnational coalitions into U.S. federal statutory law, such as advisory commissions and the input process under the Unfunded Mandates Reform Act of 1995. ${ }^{229}$ In my past work, I have examined the ways in which the U.S. EPA might involve subnational coalitions more in its process of distributing funds related to mitigation to state and local governments, an approach that could also be used by other agencies and in the context of adaptation. ${ }^{230}$ The citizens' councils formed in Alaska in the aftermath of the Exxon Valdez spill also provide a potential model for bringing smaller, suburban-city voices into the process more fully. These councils involve a range of key stakeholders in developing recommendations that then have a formal channel into the core regulatory process, an approach that could be implemented through statute or by agencies in the climate change context. ${ }^{231}$ Whether any of these models is used, or some other approach, creating more cross-cutting participation in networks would both strengthen

227. See The Aarhus Convention, Eur. Commission, http://ec.europa.eu/environment/aarhus/ (last visited Mar. 29, 2014).

228. See Svitlana Kravchenko, Procedural Rights as a Crucial Tool to Combat Climate Change, 38 Ga. J. InT'L \& Сомp. L. 613, 620 (2010). I am exploring these participatory mechanisms in more depth in collaboration with Brad Karkkainen in a project titled Climate Change, Inequality and International Lawmaking: New Governance Approaches to Addressing Abundance and Security, supported by a grant from the University of Minnesota's Institute for Advanced Study.

229. See Resnik et al., supra note 66 , at 779.

230. I have explored these citizens' councils in more depth elsewhere. See Osofsky, supra note 23, at 241; Hari M. Osofsky \& Hannah J. Wiseman, Hybrid Energy Governance, 2014 U. ILL. L. Rev. 1 (2014).

231. For a discussion of citizens' councils, see Hari M. Osofsky, Multidimensional Governance and the BP Deepwater Horizon Oil Spill, 63 FLA. L. Rev. 1077 (2011); Zygmunt J.B. Plater, Learning from Disasters: Twenty-One Years After the Exxon Valdez Oil Spill, Will Reactions to the Deepwater Horizon Blowout Finally Address the Systemic Flaws Revealed in Alaska?, 40 Envtl. L. Rep. 11041 (2010); Zygmunt J.B. Plater, Facing a Time of Counter-Revolution-The Kepone Incident and a Review of First Principles, 29 U. Rich. L. Rev. 657, 700-01 (1995); William H. Rodgers, Jr., The Most Creative Moments in the History of Environmental Law: "The Whats", 2000 U. Ill. L. Rev. 1, 22-23 (citing E-mail from Zygmunt Plater, Professor, Bos. Coll. Law Sch., to William H. Rodgers, Jr., Professor, Univ. of Wash. Sch. of Law (Feb. 2, 1998) (on file with the University of Illinois Law Review)); George J. Busenberg, Regional Citizens' Advisory Councils and Collaborative Environmental Management in the Marine Oil Trade in Alaska (unpublished manuscript), available at http://www.allacademic.com/meta/p41678_index.html (studying the two advisory councils' impacts on policy change); About Us, Prince William Sound Regional Citizens' Advisory Council, http://www.pwsrcac.org/about/ (last visited Mar. 29, 2014). 
the case for greater involvement and provide more effective representation of the diverse types of cities working on climate change.

These twin strategies of differentiated outreach and network coordination also could be used to encourage participation in suburbs that have been slower to act. As nonparticipating suburban cities interact with one another in a variety of contexts, such as in the Twin Cities metropolitan region through its regional governance structure, they can learn about the economic and social benefits leader suburbs that are similar to them have obtained through their climate change and clean energy initiatives. When a critical mass of involved citizens in those small cities become persuaded of the benefits of transitioning light bulbs, taking energy-efficiency measures, adding renewable energy to their portfolio (the Midwest has tremendous wind capacity and the Twin Cities are very sunny), or concentrating uses, these small cities often face fewer bureaucratic barriers to action than larger cities do and can act relatively quickly.

As these cities take these individual steps, they become more likely to join networks that give them support for their activities and to transition into leaders. The Twin Cities example suggests that cities do not have to be politically liberal to make that transition because many of the initial steps they take on climate change are win-wins that do not have to be framed around the politically contentious issue of climate change. Moreover, existing networks working together can reinforce the value of the smaller-scale efforts through award programs like the one that recognized Eden Prairie. 232

\section{CONCLUDING REFLECTIONS ON SOLVING GLOBAL PROBLEMS AND POLYCENTRIC CLIMATE CHANGE EFFORTS}

In the final analysis, neither of this essay's proposals is adequate to address the massive barriers to climate action with which this essay started. Even with these strategies, it is unlikely that a sufficient number of cities, large or small, will mitigate quickly enough to prevent our crossing the 450-parts-per-million carbon dioxide threshold that threatens major climate change and ever-louder calls for geoengineering. ${ }^{233}$ These networks are voluntary and participation in them cannot force action the way top-down mandates would.

But the example of these Twin Cities suburbs suggests that small, suburban cities should be an important area of focus in polycentric models for addressing the problem of climate change. As more suburbs capture the low hanging fruit under their control, major metropolitan regions will come closer to reducing emissions at levels needed. Center leader cities simply do not represent enough emissions unless joined by their smaller suburbs, which are often nimble enough to act quickly if brought on board.

Continuing to reach out through networks, whether climate change or broader ones, that include small cities not yet taking similar action, and working toward better integration of those networks with formal international and national processes,

232. See generally MCPC Best Practices, supra note 130.

233. See Johan Rockström et al., A Safe Operating Space for Humanity, 461 Nature 472, 473 (2009). 


\section{THE GEOGRAPHY OF SOLVING GLOBAL ENVIRONMENTAL PROBLEMS}

contain promise for better mitigation. They also create a framework for needed action and collaboration on adaptation that becomes more and more important as we fail to mitigate.

Sprawling U.S. metropolitan regions pose daunting mitigation challenges, but their small cities also have the potential to make incremental change. The proposed approaches, which could be implemented within existing networks and their limited resources, represent ways in which-based on the example of these Twin Cities suburbs-networks might more effectively incorporate small suburban cities. This incorporation has the potential to create action that would not have happened otherwise, both in particular cities and in multilevel governance strategies. While such action will not "solve" this "global" problem, it represents a constructive step forward. 


\section{APPENDIX}

\section{TWIN CITIES METROPOLITAN REGION COMMUNITIES'} NETWORK PARTICIPATION

\begin{tabular}{|c|c|c|c|c|c|c|}
\hline $\begin{array}{l}\text { Community } \\
\text { (Seven-County } \\
\text { Metro Area) }\end{array}$ & $\begin{array}{l}\text { GreenStep } \\
\text { Cities }^{235}\end{array}$ & $\begin{array}{l}\text { MN Energy } \\
\text { Challenge } \\
\text { Team } \\
\text { (\# Team } \\
\text { Mems. }{ }^{236} \\
\end{array}$ & \begin{tabular}{|l|} 
EPA Region 5 \\
Community \\
Climate Change \\
Initiative \\
Partner ${ }^{237}$ \\
\end{tabular} & \begin{tabular}{|l} 
Mayors \\
Agreement \\
on Climate \\
Change
\end{tabular} & $\begin{array}{l}\text { Copenhagen } \\
\text { City Climate } \\
\text { Catalogue }^{239}\end{array}$ & ICLEI $^{240}$ \\
\hline Afton & & 24 & & & & \\
\hline Andover & & 98 & & & & \\
\hline Anoka & & 82 & & & & \\
\hline Apple Valley & $6 / 2011$ & 466 & 2009 & $\begin{array}{l}\text { Mary } \\
\text { Hamann- } \\
\text { Roland }\end{array}$ & $\begin{array}{l}7 \% \text { by } 2012 \\
\text { (1990 Baseline) }\end{array}$ & \\
\hline Arden Hills & & 47 & & & & \\
\hline Bayport & & 9 & & & & \\
\hline Baytown & & 1 & & & & \\
\hline Belle Plaine & & 17 & & & & \\
\hline \multicolumn{7}{|l|}{$\begin{array}{l}\text { Belle Plaine } \\
\text { Township }\end{array}$} \\
\hline \multicolumn{7}{|l|}{$\begin{array}{l}\text { Benton } \\
\text { Township }\end{array}$} \\
\hline Bethel & & 4 & & & & \\
\hline Birchwood & & 8 & & & & \\
\hline Blaine & & 179 & & & & \\
\hline \multicolumn{7}{|l|}{$\begin{array}{l}\text { Blakeley } \\
\text { Township }\end{array}$} \\
\hline Bloomington & & 436 & & & & \\
\hline $\begin{array}{l}\text { Brooklyn } \\
\text { Center }\end{array}$ & & 104 & & \begin{tabular}{|l|} 
Tim \\
Willson
\end{tabular} & $\begin{array}{l}7 \% \text { by } 2012 \\
\text { (1990 Baseline) }\end{array}$ & \\
\hline Brooklyn Park & & 223 & & & & \\
\hline Burnsville & $4 / 2012$ & 283 & & \begin{tabular}{|l|} 
Elizabeth \\
Kautz \\
\end{tabular} & $\begin{array}{l}7 \% \text { by } 2012 \\
\text { (1990 Baseline) }\end{array}$ & \\
\hline
\end{tabular}

234. The communities listed in this column are taken from List of Community Profiles, supra note 94.

235. See GreenStep Cities List, supra note 112.

236. See City Teams, supra note 141.

237. See Region 5 Municipalities, supra note 142.

238. See List of Participating Mayors, supra note 35.

239. See supra note 144 and accompanying text.

240. See ICLEI Member List, supra note 145. 
THE GEOGRAPHY OF SOLVING GLOBAL ENVIRONMENTAL PROBLEMS

\begin{tabular}{|c|c|c|c|c|c|c|}
\hline $\begin{array}{l}\text { Community } \\
\text { (Seven-County } \\
\text { Metro Area) })^{234}\end{array}$ & $\begin{array}{l}\text { GreenStep } \\
\text { Cities }^{235}\end{array}$ & $\begin{array}{l}\text { MN Energy } \\
\text { Challenge } \\
\text { Team } \\
\text { (\#Team } \\
\text { Mems.) } \\
\end{array}$ & \begin{tabular}{|l|} 
EPA Region 5 \\
Community \\
Climate Change \\
Initiative \\
Partner ${ }^{237}$ \\
\end{tabular} & $\begin{array}{l}\text { Mayors } \\
\text { Agreement } \\
\text { on Climate } \\
\text { Change }^{238}\end{array}$ & $\begin{array}{l}\text { Copenhagen } \\
\text { City Climate } \\
\text { Catalogue }^{239}\end{array}$ & ICLEI $^{240}$ \\
\hline \multicolumn{7}{|l|}{$\begin{array}{l}\text { Camden } \\
\text { Township }\end{array}$} \\
\hline Carver & & 19 & & & & \\
\hline \multicolumn{7}{|l|}{$\begin{array}{l}\text { Castle Rock } \\
\text { Township }\end{array}$} \\
\hline \multicolumn{7}{|l|}{$\begin{array}{l}\text { Cedar Lake } \\
\text { Township }\end{array}$} \\
\hline Centerville & & 8 & & & & \\
\hline Champlin & & 100 & & & & \\
\hline Chanhassen & & 89 & & & & \\
\hline Chaska & & 85 & & & & \\
\hline Circle Pines & & 44 & & & & \\
\hline \multicolumn{7}{|l|}{ Coates } \\
\hline Cologne & & 4 & & & & \\
\hline $\begin{array}{l}\text { Columbia } \\
\text { Heights }\end{array}$ & $2 / 2013$ & 58 & & & & \\
\hline Columbus & & 4 & & & & \\
\hline Coon Rapids & & 188 & & & & \\
\hline Corcoran & & 20 & & & & \\
\hline Cottage Grove & $11 / 2010$ & 119 & & & & \\
\hline \multicolumn{7}{|l|}{$\begin{array}{l}\text { Credit River } \\
\text { Township }\end{array}$} \\
\hline Crystal & & 105 & & \begin{tabular}{|l|} 
ReNae \\
Bowman
\end{tabular} & & \\
\hline \multicolumn{7}{|l|}{$\begin{array}{l}\text { Dahlgren } \\
\text { Township }\end{array}$} \\
\hline Dayton & & 12 & & & & \\
\hline Deephaven & & 14 & & & & \\
\hline Dellwood & & 1 & & & & \\
\hline \multicolumn{7}{|l|}{$\begin{array}{l}\text { Denmark } \\
\text { Township }\end{array}$} \\
\hline Douglas & & 1 & & & & \\
\hline Eagan & $8 / 2010$ & 387 & & \begin{tabular}{|l|} 
Mike \\
Maguire
\end{tabular} & $\begin{array}{l}7 \% \text { by } 2012 \\
\text { (1990 Baseline) }\end{array}$ & \\
\hline East Bethel & & 9 & & & & \\
\hline Eden Prairie & $6 / 2011$ & 225 & & $\begin{array}{l}\text { Nancy Tyra- } \\
\text { Lukens }\end{array}$ & $\begin{array}{l}7 \% \text { by } 2012 \\
\text { (1990 Baseline) }\end{array}$ & \\
\hline Edina & $1 / 2011$ & 503 & & \begin{tabular}{|l|} 
James \\
Hovland
\end{tabular} & $\begin{array}{l}7 \% \text { by } 2012 \\
\text { (1990 Baseline) }\end{array}$ & 2007 \\
\hline
\end{tabular}




\begin{tabular}{|c|c|c|c|c|c|c|}
\hline $\begin{array}{l}\text { Community } \\
\text { (Seven-County } \\
\text { Metro Area) }^{234}\end{array}$ & $\begin{array}{l}\text { GreenStep } \\
\text { Cities }^{235}\end{array}$ & $\begin{array}{l}\text { MN Energy } \\
\text { Challenge } \\
\text { Team } \\
\text { (\#Team } \\
\text { Mems.) }{ }^{236} \\
\end{array}$ & \begin{tabular}{|l|} 
EPA Region 5 \\
Community \\
Climate Change \\
Initiative \\
Partner $^{237}$ \\
\end{tabular} & \begin{tabular}{|l} 
Mayors \\
Agreement \\
on Climate \\
Change $^{238}$
\end{tabular} & $\begin{array}{l}\text { Copenhagen } \\
\text { City Climate } \\
\text { Catalogue }^{239}\end{array}$ & ICLEI $^{240}$ \\
\hline $\begin{array}{l}\text { Elko New } \\
\text { Market }\end{array}$ & $11 / 2011$ & 2 & & & & \\
\hline \multicolumn{7}{|l|}{$\begin{array}{l}\text { Empire } \\
\text { Township }\end{array}$} \\
\hline \multicolumn{7}{|l|}{$\begin{array}{l}\text { Eureka } \\
\text { Township }\end{array}$} \\
\hline Excelsior & & 31 & & & & \\
\hline Falcon Heights & $1 / 2011$ & 79 & 2009 & $\begin{array}{l}\text { Peter } \\
\text { Lindstrom }\end{array}$ & $\begin{array}{l}\text { 7\% by } 2012 \\
\text { (1990 Baseline) }\end{array}$ & \\
\hline Farmington & $4 / 2011$ & 189 & & & & \\
\hline Forest Lake & & 89 & & & & \\
\hline Fridley & & 199 & & & & \\
\hline Gem Lake & & 2 & & & & \\
\hline Golden Valley & & 166 & & $\begin{array}{l}\text { Linda } \\
\text { Loomis }\end{array}$ & $\begin{array}{l}7 \% \text { by } 2012 \\
\text { (1990 Baseline) }\end{array}$ & 2009 \\
\hline Grant & & 5 & & & & \\
\hline Greenfield & & 5 & & & & \\
\hline \multicolumn{7}{|l|}{ Greenvale } \\
\hline \multicolumn{7}{|l|}{$\begin{array}{l}\text { Greenvale } \\
\text { Township }\end{array}$} \\
\hline Greenwood & & 3 & & & & \\
\hline \multicolumn{7}{|l|}{$\begin{array}{l}\text { Grey Cloud } \\
\text { Island } \\
\text { Township }\end{array}$} \\
\hline Ham Lake & & 32 & & & & \\
\hline Hamburg & & 3 & & & & \\
\hline Hampton & & 4 & & & & \\
\hline \multicolumn{7}{|l|}{$\begin{array}{l}\text { Hampton } \\
\text { Township }\end{array}$} \\
\hline Hancock & & 2 & & & & \\
\hline \multicolumn{7}{|l|}{ Hassan } \\
\hline Hastings & & 71 & & & & \\
\hline \multicolumn{7}{|l|}{$\begin{array}{l}\text { Helena } \\
\text { Township }\end{array}$} \\
\hline \multicolumn{7}{|l|}{ Hilltop } \\
\hline \multicolumn{7}{|l|}{$\begin{array}{l}\text { Hollywood } \\
\text { Township }\end{array}$} \\
\hline Hopkins & $10 / 2010$ & 118 & & & & \\
\hline
\end{tabular}


THE GEOGRAPHY OF SOLVING GLOBAL ENVIRONMENTAL PROBLEMS

\begin{tabular}{|c|c|c|c|c|c|c|}
\hline $\begin{array}{l}\text { Community } \\
\text { (Seven-County } \\
\text { Metro Area) })^{234}\end{array}$ & $\begin{array}{l}\text { GreenStep } \\
\text { Cities }^{235}\end{array}$ & \begin{tabular}{|l|} 
MN Energy \\
Challenge \\
Team \\
$($ \# Team \\
Mems.) ${ }^{236}$ \\
\end{tabular} & \begin{tabular}{|l|} 
EPA Region 5 \\
Community \\
Climate Change \\
Initiative \\
Partner ${ }^{237}$ \\
\end{tabular} & \begin{tabular}{|l|} 
Mayors \\
Agreement \\
on Climate \\
Change $^{238}$ \\
\end{tabular} & $\begin{array}{l}\text { Copenhagen } \\
\text { City Climate } \\
\text { Catalogue }^{239}\end{array}$ & ICLEI $^{240}$ \\
\hline Hugo & & 57 & & & & \\
\hline Independence & & 13 & & & & \\
\hline $\begin{array}{l}\text { Inver Grove } \\
\text { Heights }\end{array}$ & & 314 & & \begin{tabular}{|l|} 
George \\
Tourville \\
\end{tabular} & $\begin{array}{l}7 \% \text { by } 2012 \\
\text { (1990 Baseline) }\end{array}$ & \\
\hline $\begin{array}{l}\text { Jackson } \\
\text { Township }\end{array}$ & & 9 & & & & \\
\hline Jordan & & 22 & & & & \\
\hline Lake Elmo & $5 / 2012$ & 38 & & & & \\
\hline $\begin{array}{l}\text { Lake St. Croix } \\
\text { Beach }\end{array}$ & & 1 & & & & \\
\hline Lakeland & & 30 & & & & \\
\hline \multicolumn{7}{|l|}{$\begin{array}{l}\text { Lakeland } \\
\text { Shores }\end{array}$} \\
\hline \multicolumn{7}{|l|}{$\begin{array}{l}\text { Laketown } \\
\text { Township }\end{array}$} \\
\hline Lakeville & & 201 & & & & \\
\hline Landfall & & 2 & & & & \\
\hline Lauderdale & & 12 & & & & \\
\hline Lexington & & 9 & & & & \\
\hline Lilydale & & 3 & & & & \\
\hline Lino Lakes & & 59 & & & & \\
\hline \multicolumn{7}{|l|}{$\begin{array}{l}\text { Linwood } \\
\text { Township }\end{array}$} \\
\hline Little Canada & & 33 & & & & \\
\hline Long Lake & & 41 & & & & \\
\hline Loretto & & 21 & & & & \\
\hline \multicolumn{7}{|l|}{$\begin{array}{l}\text { Louisville } \\
\text { Township }\end{array}$} \\
\hline Mahtomedi & $10 / 2010$ & 58 & & $\begin{array}{l}\text { Judson } \\
\text { Marshall }\end{array}$ & $\begin{array}{l}7 \% \text { by } 2012 \\
\text { (1990 Baseline) }\end{array}$ & 2008 \\
\hline Maple Grove & $12 / 2012$ & 224 & & & & \\
\hline Maple Plain & & 49 & & & & \\
\hline Maplewood & $12 / 2010$ & 135 & Prior to 2009 & $\begin{array}{l}\text { Diana } \\
\text { Longrie }\end{array}$ & $\begin{array}{l}7 \% \text { by } 2012 \\
\text { (1990 Baseline) }\end{array}$ & \\
\hline $\begin{array}{l}\text { Marine on St. } \\
\text { Croix }\end{array}$ & & 10 & & & & \\
\hline \multicolumn{7}{|l|}{$\begin{array}{l}\text { Marshan } \\
\text { Township }\end{array}$} \\
\hline MayTownship & & & & & & \\
\hline
\end{tabular}




\begin{tabular}{|c|c|c|c|c|c|c|}
\hline \begin{tabular}{|l|} 
Community \\
(Seven-County \\
Metro Area) ${ }^{234}$
\end{tabular} & $\begin{array}{l}\text { GreenStep } \\
\text { Cities }^{235}\end{array}$ & $\begin{array}{l}\text { MN Energy } \\
\text { Challenge } \\
\text { Team } \\
\text { (\# Team } \\
\text { Mems. }{ }^{236} \\
\end{array}$ & \begin{tabular}{|l|} 
EPA Region 5 \\
Community \\
Climate Change \\
Initiative \\
Partner $^{237}$ \\
\end{tabular} & \begin{tabular}{|l|} 
Mayors \\
Agreement \\
on Climate \\
Change $^{238}$
\end{tabular} & \begin{tabular}{|l|} 
Copenhagen \\
City Climate \\
Catalogue $^{239}$
\end{tabular} & ICLEI $^{240}$ \\
\hline Mayer & & 6 & & & & \\
\hline Medicine Lake & & 1 & & & & \\
\hline Medina & & 16 & & & & \\
\hline Mendota & & 4 & & & & \\
\hline $\begin{array}{l}\text { Mendota } \\
\text { Heights }\end{array}$ & & 80 & & & & \\
\hline Miesville & & 1 & & & & \\
\hline Minneapolis & & 9,798 & & R.T. Rybak & $\begin{array}{l}12 \% \text { by } 2012 ; \\
20 \% \text { by } 2020 ; \\
80 \% \text { by } 2050 \\
\text { (2006 Baseline) }\end{array}$ & 1992 \\
\hline Minnetonka & $11 / 2013$ & 307 & & \begin{tabular}{|l|} 
Janis \\
Callison
\end{tabular} & $\begin{array}{l}7 \% \text { by } 2012 \\
\text { (1990 Baseline) }\end{array}$ & \\
\hline $\begin{array}{l}\text { Minnetonka } \\
\text { Beach }\end{array}$ & & 1 & & & & \\
\hline Minnetrista & & 8 & & & & \\
\hline Mound & & 41 & & & & \\
\hline Mounds View & & 64 & & & & \\
\hline New Brighton & & 149 & & & & \\
\hline \multicolumn{7}{|l|}{ New Germany } \\
\hline New Hope & & 86 & & & & \\
\hline \multicolumn{7}{|l|}{$\begin{array}{l}\text { New Market } \\
\text { Township }\end{array}$} \\
\hline \multicolumn{7}{|l|}{ New Trier } \\
\hline Newport & $4 / 2012$ & 20 & & & & \\
\hline \multicolumn{7}{|l|}{$\begin{array}{l}\text { Nininger } \\
\text { Township }\end{array}$} \\
\hline North Oaks & & 29 & & & & \\
\hline North St. Paul & $7 / 2012$ & 32 & & & & \\
\hline $\begin{array}{l}\text { Norwood } \\
\text { Young America }\end{array}$ & & 3 & & & & \\
\hline \multicolumn{7}{|l|}{ Nowthen } \\
\hline Oak Grove & & 16 & & & & \\
\hline $\begin{array}{l}\text { Oak Park } \\
\text { Heights }\end{array}$ & & 2 & & \begin{tabular}{|l|} 
David \\
Beudet
\end{tabular} & $\begin{array}{l}7 \% \text { by } 2012 \\
\text { (1990 Baseline) }\end{array}$ & \\
\hline Oakdale & $3 / 2011$ & 189 & 2009 & & & 2008 \\
\hline Orono & & 34 & & & & \\
\hline Osseo & & 28 & & & & \\
\hline
\end{tabular}


THE GEOGRAPHY OF SOLVING GLOBAL ENVIRONMENTAL PROBLEMS

\begin{tabular}{|c|c|c|c|c|c|c|}
\hline $\begin{array}{l}\text { Community } \\
\text { (Seven-County } \\
\text { Metro Area) }^{234}\end{array}$ & $\begin{array}{l}\text { GreenStep } \\
\text { Cities }^{235}\end{array}$ & \begin{tabular}{|l|} 
MN Energy \\
Challenge \\
Team \\
$($ \#Team \\
Mems.) ${ }^{236}$ \\
\end{tabular} & \begin{tabular}{|l} 
EPA Region 5 \\
Community \\
Climate Change \\
Initiative \\
Partner ${ }^{237}$ \\
\end{tabular} & \begin{tabular}{|l|} 
Mayors \\
Agreement \\
on Climate \\
Change $^{238}$ \\
\end{tabular} & $\begin{array}{l}\text { Copenhagen } \\
\text { City Climate } \\
\text { Catalogue }^{239}\end{array}$ & ICLEI $^{240}$ \\
\hline Pine Springs & & 2 & & & & \\
\hline Plymouth & & 339 & & & & \\
\hline Prior Lake & & 496 & & & & \\
\hline Ramsey & & 131 & & & & \\
\hline Randolph & & 5 & & & & \\
\hline \multicolumn{7}{|l|}{$\begin{array}{l}\text { Randolph } \\
\text { Township }\end{array}$} \\
\hline \multicolumn{7}{|l|}{$\begin{array}{l}\text { Ravenna } \\
\text { Township }\end{array}$} \\
\hline Richfield & $1 / 2012$ & 240 & & & & \\
\hline Robbinsdale & & 130 & & & & \\
\hline Rogers & $12 / 2011$ & 27 & & & & \\
\hline Rosemount & $12 / 2011$ & 2,257 & & \begin{tabular}{|l|} 
William \\
Droste \\
\end{tabular} & \begin{tabular}{|l|}
$7 \%$ by 2012 \\
(1990 Baseline)
\end{tabular} & \\
\hline Roseville & & 294 & 2009 & \begin{tabular}{|l|} 
Craig \\
Klausing \\
\end{tabular} & $\begin{array}{l}7 \% \text { by } 2012 \\
\text { (1990 Baseline) }\end{array}$ & 2006 \\
\hline \multicolumn{7}{|l|}{$\begin{array}{l}\text { San Franscisco } \\
\text { Township }\end{array}$} \\
\hline \multicolumn{7}{|l|}{$\begin{array}{l}\text { Sand Creek } \\
\text { Township }\end{array}$} \\
\hline Savage & & 148 & & & & \\
\hline Scandia & & 9 & & & & \\
\hline \multicolumn{7}{|l|}{$\begin{array}{l}\text { Sciota } \\
\text { Township }\end{array}$} \\
\hline Shakopee & & 130 & & & & \\
\hline Shoreview & $1 / 2013$ & 146 & & & & \\
\hline Shorewood & 6/2011 & 34 & & & & \\
\hline South St. Paul & & 67 & & & & \\
\hline $\begin{array}{l}\text { Spring Lake } \\
\text { Park }\end{array}$ & & 14 & & & & \\
\hline \multicolumn{7}{|l|}{$\begin{array}{l}\text { Spring Lake } \\
\text { Township }\end{array}$} \\
\hline Spring Park & & 1 & & & & \\
\hline St. Anthony & $2 / 2011$ & 28 & & & & \\
\hline St. Bonifacious & & 9 & & & & \\
\hline St. Francis & & 13 & & & & \\
\hline $\begin{array}{l}\text { St. Lawrence } \\
\text { Township }\end{array}$ & & & & & & \\
\hline
\end{tabular}




\begin{tabular}{|c|c|c|c|c|c|c|}
\hline \begin{tabular}{|l|} 
Community \\
(Seven-County \\
Metro Area) ${ }^{234}$
\end{tabular} & $\begin{array}{l}\text { GreenStep } \\
\text { Cities }^{235}\end{array}$ & $\begin{array}{l}\text { MN Energy } \\
\text { Challenge } \\
\text { Team } \\
\text { (\# Team } \\
\text { Mems. }{ }^{236} \\
\end{array}$ & \begin{tabular}{|l|} 
EPA Region 5 \\
Community \\
Climate Change \\
Initiative \\
Partner $^{237}$ \\
\end{tabular} & \begin{tabular}{|l} 
Mayors \\
Agreement \\
on Climate \\
Change $^{238}$
\end{tabular} & \begin{tabular}{|l|} 
Copenhagen \\
City Climate \\
Catalogue $^{239}$
\end{tabular} & ICLEI $^{240}$ \\
\hline St. Louis Park & $6 / 2012$ & 479 & & & & \\
\hline \multicolumn{7}{|l|}{ St. Marys Point } \\
\hline St. Paul & & 2,840 & Prior to 2009 & \begin{tabular}{|l|} 
Chris \\
Coleman
\end{tabular} & $\begin{array}{l}7 \% \text { by } 2012 \\
\text { (1990 Baseline) }\end{array}$ & 1992 \\
\hline St. Paul Park & $2 / 2013$ & 18 & & & & \\
\hline Stillwater & & 226 & & & & \\
\hline \multicolumn{7}{|l|}{$\begin{array}{l}\text { Stillwater } \\
\text { Township }\end{array}$} \\
\hline Sunfish Lake & & 9 & & Molly Park & $\begin{array}{l}7 \% \text { by } 2012 \\
\text { (1990 Baseline) }\end{array}$ & \\
\hline Tonka Bay & & 6 & & & & \\
\hline $\begin{array}{l}\text { Vadnais } \\
\text { Heights }\end{array}$ & & 47 & & & & \\
\hline \multicolumn{7}{|l|}{ Vermillion } \\
\hline \multicolumn{7}{|l|}{$\begin{array}{l}\text { Vermillion } \\
\text { Township }\end{array}$} \\
\hline Victoria & $1 / 2012$ & 23 & & & & \\
\hline Waconia & & 19 & & & & \\
\hline \multicolumn{7}{|l|}{$\begin{array}{l}\text { Waconia } \\
\text { Township }\end{array}$} \\
\hline \multicolumn{7}{|l|}{$\begin{array}{l}\text { Waterford } \\
\text { Township }\end{array}$} \\
\hline Watertown & & 13 & & & & \\
\hline \multicolumn{7}{|l|}{$\begin{array}{l}\text { Watertown } \\
\text { Township }\end{array}$} \\
\hline Wayzata & & 49 & & & & \\
\hline \multicolumn{7}{|l|}{$\begin{array}{l}\text { West Lakeland } \\
\text { Township }\end{array}$} \\
\hline West St. Paul & & 65 & & & & \\
\hline $\begin{array}{l}\text { White Bear } \\
\text { Lake }\end{array}$ & $12 / 2011$ & 141 & & Paul Auger & $\begin{array}{l}7 \% \text { by } 2012 \\
\text { (1990 Baseline) }\end{array}$ & \\
\hline $\begin{array}{l}\text { White Bear } \\
\text { Township }\end{array}$ & & 1 & & & & \\
\hline Willernie & & 2 & & & & \\
\hline Woodbury & $1 / 2013$ & 258 & & \begin{tabular}{|l|} 
William \\
Hargis \\
\end{tabular} & \begin{tabular}{|l|}
$7 \%$ by 2012 \\
(1990 Baseline)
\end{tabular} & 2011 \\
\hline \multicolumn{7}{|l|}{ Woodland } \\
\hline $\begin{array}{l}\text { Young America } \\
\text { Township }\end{array}$ & & 3 & & & & \\
\hline Totals: 183 & 30 & 26,068 & 6 & 21 & 20 & 8 \\
\hline
\end{tabular}

